\title{
ICT as "Knowledge Management" for Assessing Sustainable Consumption and Production in Supply Chains
}

\author{
Surbhi Uniyal, Graphic Era University, Dehradun, India \\ Sachin Kumar Mangla, Plymouth Business School, University of Plymouth, UK \\ Pappu R. S. Sarma, Production and Operations Management, Indian Institute of Management, Vishakhapatnam, India \\ Ming-Lang Tseng, Institute of Innovation and Circular Economy, Asia University, Taichung, Taiwan \\ Pravin Patil, Graphic Era University, Dehradun, India
}

\begin{abstract}
The significance of sustainability is continually expanding among researchers, policymakers, and decision makers. To improve the efficiency of value chain activities such as manufacturing, distribution, and consumption, an innovative research solution has been proposed: 'Sustainable Consumption and Production (SCP) through Information and Communication Technology (ICT)'. Sustainability through ICT is significant for the industry in terms of its sustainable effects on production processes, environment, and community. This research seeks to gauge ICT - as knowledge management-for industries in the successful adoption and execution of SCP. In so doing, potential key ICT-based factors to SCP are identified from the literature and experts' feedback. The present work suggests a decision framework for assessing the interrelationships among and between the ICT oriented factors by utilizing graph theory and matrix approach. Data for this work derives from three automotive companies operating in India. From findings, 'Governance and Management', is the topmost factor for the adoption of sustainable consumption and production in value chains. The relationship among the index values is further evaluated using Spearman's rank correlation coefficient. This research can facilitate practitioners, government agencies, and customers for a better understanding of ICT-driven factors in managing resources, reducing waste, and improving cost, which would further help in meeting sustainable development goals of the United Nations of responsible consumption and production and innovation, industry, and infrastructure.
\end{abstract}

\section{KEYWORDS}

Graph Theory, ICT-Based Factors, Indian Automotive Company, Knowledge Management, Matrix Approach, Spearman's Rank Correlation Coefficient, Supply Chain Management, Sustainable Consumption and Production

This article, published as an Open Access article on February 4, 2021 in the journal, Journal of Global Information Management (converted to gold Open Access January 1, 2021), is distributed under the terms of the Creative Commons Attribution License (http://creativecommons. org/licenses/by/4.0/) which permits unrestricted use, distribution, and production in any medium, provided the author of the original work and original publication source are properly credited. 


\section{INTRODUCTION}

The present industrial consumption and production patterns provide huge impacts on the environment, for example, a worldwide increase in temperature, loss of biodiversity, air, soil, and water contamination, etc. In this sense, sustainable consumption and production (SCP) are increasing attention among stakeholders (Erlandsson and Tillman, 2009), which pushes the industries to adopt SCP practices along the value chain (Koplin et al., 2007). Focusing on SCP in an industry helps firms to lead the market with a focus on higher processes, people, and planet gains (Colbert and Kurucz, 2007; Porter and Kramer, 2006).

Information and communication technologies (ICT) are contributing to a sustainable society (Cerri and Terzi, 2016). In line with this, in order to improve the efficiency of business activities such as manufacturing, production, and consumption, an innovative research solution has been proposed as 'Sustainable Consumption and Production through Information and Communication Technology' (Hilty and Aebischer, 2015; Grant et al.,(2019). Sustainability through ICT modules has received huge recognition in the industry in terms of sustainable effects on production processes and energy use (Lu et al., 2014).

From an industrial context, there is an immense potential for ICT to support sustainable development (Klimova et al., 2016; Morrar et al.,2019) in its various activities such as handling, transport, recovery, stockpiling, data representation, and exchange of information through different equipment, sensors, data administration instruments, etc. (Yang and Huang, 2016; Taylor, 2015; Hack and Berg, 2014). ICT can provide huge advantages to business in terms of cost savings, workers' satisfaction, and reduction of waste by optimizing the resources, enhancing communication between members, supporting management functions, and improving the decision-making capabilities (Goodrum et al., 2016).

ICT has turned into a significant criterion for SCP activities; however, the research on ICT developments and application is somewhat limited in the context of SCP (Chugh et al., 2016). The reason is lack of infrastructure and facilities, lack of expertise, governance, and finance, etc (Clemons and Row, 1991). In nutshell, SCP can be accomplished by the selection of the right ICT practices in production, configuration, consumption, and disposal to achieve growth, gain efficiency, and reduce cost and time (Hassani et al., 2017).

The research questions that this paper proposes are:

1. What are the ICT based factors for successful adoption and execution of SCP in Indian automotive companies?

2. How the factors are organized based on their importance that influences the effectiveness of the case companies?

The current paper listed the following research objectives:

3. To recognize the factors of ICT relevant to SCP in an industrial context.

4. To model the factors to establish their priority.

5. To test the applicability of the proposed framework in the industry.

This work aims to list and evaluate ICT based factors, which are responsible for the implementation of SCP in an industrial context. These factors of ICT have a noteworthy effect on the environment, economy, and society, and help enhance the proficiency and profitability of the automotive value chain. The factors linked to ICT are identified through an intense literature survey and experts' feedback. The data for this work has been taken from three automobile companies from India. In this objective, we computed the adoption index values for the suggested framework of factors by taking multiple 
automotive case companies through the Graph Theory and Matrix Approach (GTMA) technique. The applicability of the proposed framework is tested by Spearman's rank correlation coefficient.

The automotive industry is an important division with a substantial number of medium and small measured automotive providers, however, due to rising prices of oil and scarcity of natural resources; it becomes the most required sector for technology advancements and innovation. The Indian automobile business has turned out to be the world's fourth-leading automotive industry (IBEF, 2018). Concurrently, the Indian automotive industry needs to cut its carbon emissions, improve cost efficiency, and contribute to human welfare through responsible consumption and production. In this sense, ICT advancements can help Indian automotive industries to adopt and promote SCP practices in business.

The rest of the paper includes -Relevant literature is described in Section 2. The methodology of the research is described in Section 3. Data analysis and results are given in Section 4. A discussion of findings is explained in Section 5. Research implications are explained in Section 6 and finally, conclusions and future work is described in Section 7.

\section{LITERATURE REVIEW}

\subsection{SCP}

SCP is crucial for the sustainability of the industry (Akenji and Bengtsson, 2014). In 1994 at Oslo Symposium, researchers described the SCP as "the utilization of administrations and related items, which react to fundamental needs and bring a superior personal satisfaction while limiting the use of regular assets and harmful materials and additionally the outflows of waste and toxins over the existence cycle of the administration or item so as not to endanger the necessities of further ages"(Clark, 2007). SCP works on the Triple bottom line (TBL) concept of improving financial-societal-environmental performances in business. In addition, governance is also important in improving a company's productivity along with its social and ecological objectives (Porter and Kramer, 2006).

Being a leader in environmental practices, developed countries like Norway, Sweden, and Switzerland are far ahead of developing countries like India in SCP adoption and implementation (Ansari et al., 2010). Being positively linked to ecological and financial performance (Russo and Fouts, 1997), firms of developing and developed countries involved in SCP efforts can achieve high market appreciation (Bansal and Clelland, 2004). This needs to be integrating each member of the supply chain like suppliers, consumers, controllers, investors with organizational sustainability missions of SCP into its activities through a network of communications. This further helps in empowering a web of information and learning trade amongst firms and their value chain collaborators along the life cycle of a venture (Gan et al., 2015). SCP can be targeted against different measures, however, concerning ICT, it aims to lower the energy consumption rate (Agrawal and Agarwal, 2012), increasing social and environmental awareness, reducing greenhouse gas discharge (Andreopoulou, 2012), adopting of innovative technology for less generation of waste (Ansari et al., 2010). The industries concentrating on these quadrants can easily provide a special position to consumer requirements (Porter and Kramer, 2006). ICT can help in diminishing the assets required to streamline operations and improving overall process efficiency (Klimova et al., 2016). According to Gullo and Haygood, (2010), the acceptance of innovative sustainability practices in industries can increase the profit margin to $38 \%$. Therefore, a need arises to recognize ICT as a driver in establishing SCP in business.

\subsection{ICT as a Driver in SCP Adoption}

ICT models are crucial for business effectiveness (Aral and Weill, 2007). Researchers began to assess the effect of ICT in a pragmatic way since the first decade of the 21st century (Zhou et al., 2018), whereas it was implemented widely in production function since the 1990s. ICT with the internet economy seems to increase the efficiency in each dimension of sustainability (people, process, and 
the planet). Brindley and Oxborrow (2014) stated that the network of information exchange must be in line with the market trends to meet the transformations or interruptions in the supply chain. Hack and Berg (2014) declared that ICT provides clear information, improves responsibility, amplify precision of records, empowers automation and incorporation of exercises, and creates knowledge for better basic leadership and optimization of resources. Mignoneet al. (2016) considered profitability as an advantage with digitized and customized document administration systems by including fragmented processes of an assignment through automated and streamlined correspondence. In a holistic view, ICT advances the sharing of information (Simchi-Levi et al., 2008), optimize the flow of materials (Lee, 2000), provides flexibility to the operations (Keller and Heiko, 2014), streamline monetary functions (Rai et al., 2006) and improve communication among the members (Yang and Huang, 2016; Goodrum et al., 2016) by integrating IT platforms across the organizational supply chains (Lai et al., 2015). SCP by ICT is also improving the efficiency of the value chain by capturing and sharing information, advancing transportation, reducing consumption of material and electricity, and utilizing automated technologies (Hilty and Aebischer, 2015). Wu and Raghupathi, 2015 strategically examine strategic cooperation between ICT and sustainability by incorporating certain factors and stated that ICT can promote the SCP of the country. Techatassanasoontorn et al., 2011 examined four factors of socio-culture on the development of ICT efforts in Thailand and commented that the growth of Thailand is depending upon the increasing funds and enhancement in innovation and technology. Gholami et al., 2010 examines the relationship between ICT proliferation and human development using data from 52 developed and developing countries by conducting a panel regression analysis. According to Majid (2018), ICT has proved effective in fighting un-sustainability and poverty and has the potential to be helpful in the execution of sustainable consumption and production patterns. Majeed (2018), conducts a comparative empirical analysis of 132 developed and developing economies to explore ICT's link with the environment and concludes that ICT has the power to determine the ecological future of the world.

In this sense, the focus should be shifted towards applying clean technologies instead of cleaning technologies. ICT can contribute to SCP in terms of making, empowering, and encouraging continuous blueprints of production and consumption to reduce product and energy consumption in their life cycle (Hilty and Aebischer, 2015). Hosseini et al. (2017) successfully created a model for construction projects of Iran and concluded that sustainability can be accomplished by ICT through the substitution of media, optimization of processes, and control externalization. Chugh et al. (2016) determined the awareness of professionals towards the environmentally sustainable practices of ICT in India. Klimova and Rondeau (2017) analyzed the structure for the execution of continuous growth of the ICT curriculum and the recent trend and approach for the expansion of the academic agenda in the field of learning. Zhou et al. (2018) utilized the approach of three-tier structural decomposition analysis (SDA) to analyze the major factors after China's energy intensity changes due to the importance of ICT. Dao et al. (2011) discuss the function of information technology in sustainability instead of a reduction in energy consumption. Luthra et al. (2018) identified the drivers of ICT, which are important to establish sustainability in business. Hassani et al. (2017) reviewed the importance of quantitative and non-quantitative effects of both innovation and technology in the petrochemical and petroleum industries. Sadorsky (2012) further inspected ICT's impact on the utilization of power in rising economies and with the help of a dynamic demand model, concludes that there is an affirmative and arithmetic connection among ICT and power utilization. Forster (2015) considered the case of the German automotive industry and utilized innovation insights to identify the advances and procedures applicable to sustainable production. According to Romm (2002), in the USA, the industries adopting ICT practices are consuming less energy than conventional manufacturing industries. In addition, Takase and Murota (2004) studied the reasons for ICT as far as utilization of energy and $\mathrm{CO}_{2}$ discharges for Japan and the U.S.

Thus, in order to achieve SCP, ICT based factors and processes are crucial for industries. In view of the above considerations, ICT resources can act as a change agent for SCP and hence develop 
Table 1. ICT driven factors to adopt SCP

\begin{tabular}{|c|c|c|}
\hline S.No. & ICT Factors & References \\
\hline \multicolumn{3}{|c|}{ (i) Governance and Management (GM) } \\
\hline 1 & $\begin{array}{l}\text { Government policies and encouragement in SCP } \\
\text { through information system (GM1) }\end{array}$ & Zhang et al., 2015; Elliot, 2007; Puri and Sahay, 2007 \\
\hline 2 & $\begin{array}{l}\text { Higher coordination and cooperation among } \\
\text { members (GM2) }\end{array}$ & $\begin{array}{l}\text { Pero et al. (2017); Murugesan, 2008; Matos and Hall, } \\
2007\end{array}$ \\
\hline 3 & Change management (GM3) & Tatoglu et al. (2016); Gunasekaran and Ngai, (2008) \\
\hline 4 & $\begin{array}{l}\text { Advanced digital infrastructure and cost-effective } \\
\text { models in the era of Industry } 4.0 \text { (GM4) }\end{array}$ & $\begin{array}{l}\text { Hossein et al., 2017; Dao et al., 2011; Jonsson and } \\
\text { Mattsson, } 2013\end{array}$ \\
\hline 5 & Competitiveness and globalization (GM5) & Cepolina, 2011 \\
\hline \multicolumn{3}{|c|}{ (ii) Technology and Skills (TS) } \\
\hline 1 & $\begin{array}{l}\text { Understanding and awareness of ICT tools among } \\
\text { stakeholders (TS1) }\end{array}$ & Hossein et al., 2017; Kausar et al., 2017 \\
\hline 2 & $\begin{array}{l}\text { Human expertise in ICT tools and techniques } \\
\text { (TS2) }\end{array}$ & Clemons and Row, 1991; Abdulrahman et al., 2014 \\
\hline 3 & $\begin{array}{l}\text { Technological up-gradations and process } \\
\text { innovation (TS3) }\end{array}$ & $\begin{array}{l}\text { Ansari et al., 2010; Erek, 2011; Kausar et al. 2017; El } \\
\text { Kadiri et al., } 2016\end{array}$ \\
\hline \multicolumn{3}{|c|}{ (iii) Legal \& Ethical (LE) } \\
\hline 1 & Cultural factors (LE1) & Ahuja et al., 2009; Hearn et al., 2005; Orlikowski, 2008 \\
\hline 2 & $\begin{array}{l}\text { Transparency mechanism for responsible } \\
\text { management (LE2) }\end{array}$ & $\begin{array}{l}\text { Ansari et al., 2010; Hossein et al., 2017; Greco et al., } \\
2015\end{array}$ \\
\hline 3 & $\begin{array}{l}\text { Higher security, privacy, and trust in the business } \\
\text { environment (LE3) }\end{array}$ & $\begin{array}{l}\text { Keller and Heiko, 2014; Ageron et al., 2012; Trentesaux et } \\
\text { al., 2016; Du et al.,2011 }\end{array}$ \\
\hline \multicolumn{3}{|c|}{ (iv) Social (S) } \\
\hline 1 & Integration of people-process-planet benefits (S1) & Pero et al. (2017); Van Breedam, 2016; Zhang et al., 2011 \\
\hline 2 & Customer preferences towards ICT in SCP (S2) & Aleke et al., 2011; Apulu et al., 2011; Kagaari et al., 2010 \\
\hline 3 & Managing people and supply chain resources (S3) & Dao et al., 2011 \\
\hline 4 & Encourage private and foreign investment (S4) & Vickery et al. (2003); Saguy and Sirotinskaya (2014) \\
\hline
\end{tabular}

sustainable development culture. In the current work, the ICT driven factors of SCP are recognized through the literature and the discussion with experts. Initially, the ICT driven factors are listed by searching the keywords 'Information and communication technology in sustainable consumption and production', 'Factors/Drivers/Enablers of Information and communication technology', 'Information and communication technology in the supply chain', 'Sustainability by Information and Communication Technology'. Later, we discussed the factors with experts for their agreement. The factors are presented in Table 1.

\subsection{Research Gaps}

The present work documented the following research gaps:

- Based on the "Knowledge-to-Action" gap in the perspective of value chains, the ICT function is contributing to substantial e-waste created in a developing country like India (Chugh et al., 2016). Because of e-waste volume and toxicity (Wath et al., 2010), ICT quickly turning into a noteworthy 
area of waste generation. Thus, it is important to minimize the gap between information and work, so that ICT can help to reduce e-waste and contribute to responsible consumption and production.

- In order to achieve SCP, ICT driven change management is important in business (Heeks, 2010). Therefore, there is a need for adequate research in relation to exploring drivers/factors to ICT for the effective use of energy management, technology, and environmental degradation related practices for responsible consumption and production (Pick and Azari, 2011).

- Poor ICT investment choices can unfavorably influence profitability (Taylor, 2015) whereas inadequate usage of ICT can negatively affect the community and environment (Hack and Berg, 2014). Any insufficiency in coordinating ICT applications may further deform the capability of the framework to progress and convey critical information with respect to environmental effects to all the members in the SCP focused value chain. (Zhang et al., 2015). Thus, it is imperative for market players and government bodies to manage information and establish frameworks for understanding the causal relationships among factors to develop effective SCP concepts in the industry. There is negligible research that offered the causal relations for the ICT driven factors in SCP adoption in an industrial context.

To address the above-listed research gaps, the current work is one of the initial efforts to evaluate ICT based factors to drive SCP concepts taking a case of multiple Indian automotive companies in India through GTMA and Spearman's rank correlation coefficient.

\section{SOLUTION METHODOLOGY}

In this work, we utilized the GTMA based approach as the solution methodology. The GTMA analyzes the ICT driven factors to SCP and ranks them according to their index values. Spearman's rank correlation coefficient is utilized to calculate the relationship among the index values of adopting ICT driven factors to SCP. The Spearman's rank correlation coefficient can describe the connection among the rankings of two variables. The suggested framework for this work is shown in Figure 1.

\subsection{GTMA}

GTMA is a flexible and methodical tool for modeling and analyses in various areas of engineering and sciences like operation research, group theory, economics, linguistics, stochastic process by converting qualitative values to quantitative numbers (Grover et al, 2006). GTMA is a study of relationships with a set of nodes and connections that can abstract anything from city layout to computer data. A graphical representation is the visual display of data that will help us present the data in a meaningful way and it provides data that is very easy to understand and helps management to make decisions. GTMA came into existence in 1736 by Leonhard Euler for solving the problem of the Konigsberg Bridge. GTMA is extensively used by investigators in diverse domains, such as SCM, analyze contractors, GSCM, diesel engines (Darvish et al., 2009; Faisal et al., 2007; Muduli et al., 2011; Geetha and Sekar, 2016). GTMA is preferred over Analytic Network Process (ANP), Decision-Making Trial and Evaluation Laboratory (DEMATEL), Analytical Hierarchical Process (AHP) as it is capable of solving the system implicitly and explicitly and evaluates the inter-relationship among variables in a system as well (Muduli et al., 2013; Jangra et al., 2011). Graph theory helps in analyzing and understanding the system completely by recognizing the component level and subsystem to the system level. GTMA can visually represent the inter-relationship between all the factors using diagraph. GTMA provides index value to optimally compare and rank the factors. Following are the steps of GTMA (Muduli et al., 2013):

Step 1. Identification of the Factors: The factors relevant to SCP adoption are identified using literature review and expert's opinions. 
Figure 1. Framework for this research

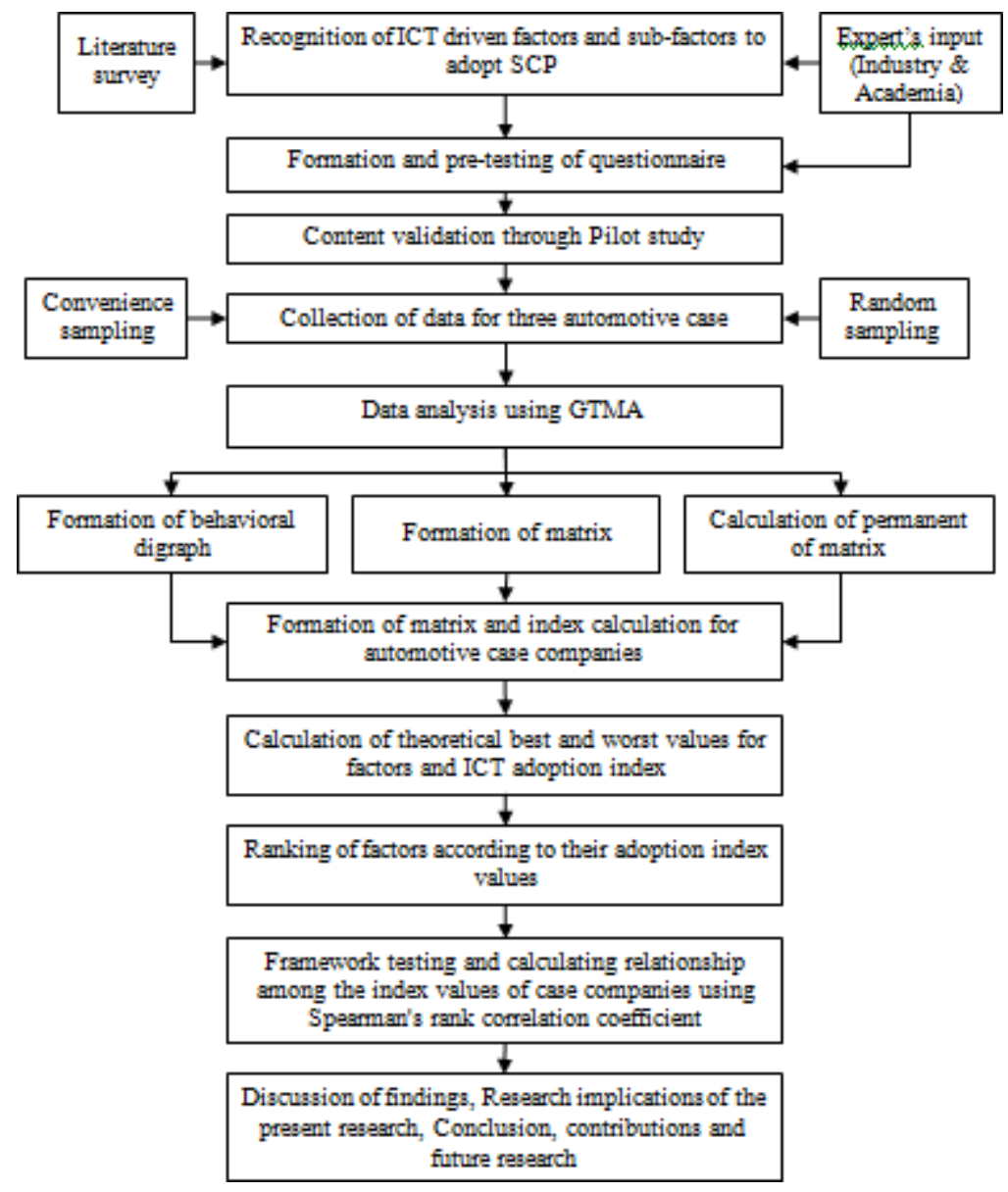

Step 2. Development of the Digraph: The digraph of the recognized factors was developed by analyzing their interdependencies. A behavioral digraph is a graph that provides direction to the factors based on their interdependencies. The digraph is provided with nodes and edges where a node represents all the factors of SCP whereas directed edges represent the inter-dependencies amongst the factors. If the arrow/directed edging is in the direction of ' $y$ ', it represents the factor ' $x$ ' has relative significance above factor ' $y$ ' which is represented as ' $c_{x y}$ ', and if the arrow/ directed edging is towards ' $x$ ', it signifies the relative importance of factor ' $y$ ' above factor ' $x$ ' and is represented as 'c $c_{\mathrm{yx}}$ ' (Rao et al., 2007).

Step 3. Development of the Matrix: The digraphs developed in step 2 are transformed into matrices using Table 2.

Step 4. Permanent of the Matrix: Cauchy introduced a class of symmetric functions of the matrix for computing its determinant. Later, Muir named it permanents (Nourani et al., 1999). The expression for obtaining the permanents of a matrix is the same as that of determinants with just one difference that in permanents the negative sign is replaced by a positive sign (Faisal et al., 2007; Rao et al., 2006). The permanent of the matrix is obtained using the standard expression (Jurkat and Ryser, 1966) as provided in Eq. (1): 
Table 2. Scale for relative importance of factors $\left(c_{x y}\right)$

\begin{tabular}{|c|c|c|}
\hline \multirow{2}{*}{ Definition } & \multicolumn{2}{|c|}{ Relative Importance of Factors } \\
\hline & $\mathbf{c}_{\mathrm{xy}}$ & $c_{y x}=10-c_{x y}$ \\
\hline Evaluating factors are evenly essential & 5 & 5 \\
\hline An evaluating factor is moderately essential above other factor & 6 & 4 \\
\hline An evaluating factor is strongly essential above other factor & 7 & 3 \\
\hline An evaluating factor is very strongly essential above other factor & 8 & 2 \\
\hline An evaluating factor is extremely essential above other factor & 9 & 1 \\
\hline An evaluating factor is exceptionally above other factor & 10 & 0 \\
\hline
\end{tabular}

(Source: Muduli et al., 2013)

$$
\begin{aligned}
& \operatorname{Per}(F)=\prod_{x=1}^{6} F_{x}+\sum_{x=1}^{5} \sum_{y=x+1}^{6} \sum_{z=1}^{3} \sum_{p=z+1}^{4} \sum_{q=p+1}^{5} \sum_{r=q+1}^{6}\left(c_{x y} c_{y x}\right) F_{z} F_{p} F_{q} F_{r} \\
& +\sum_{x=1}^{4} \sum_{y=x+1}^{5} \sum_{z=y+1}^{6} \sum_{p=1}^{4} \sum_{q=p+1}^{5} \sum_{r=q+1}^{6}\left(c_{x y} c_{y z} c_{z x}+c_{x z} c_{z y} c_{y x}\right) F_{p} F_{q} F_{r} \\
& +\left(\begin{array}{l}
\sum_{x=1}^{3} \sum_{y=x+1}^{6} \sum_{z=x+1}^{5} \sum_{p=x+2}^{6} \sum_{q=1}^{5} \sum_{r=q+1}^{6}\left(c_{x y} c_{y x}\right)\left(c_{z p} c_{p z}\right) F_{q} F_{r}+ \\
\sum_{x=1}^{3} \sum_{y=x+1}^{5} \sum_{z=x+1}^{6} \sum_{p=y+1}^{6} \sum_{q=1}^{5} \sum_{r=q+1}^{6}\left(c_{x y} c_{y z} c_{z p} c_{p x}+c_{x p} c_{p z} c_{z y} c_{y x}\right) F_{q} F_{r}
\end{array}\right) \\
& +\left(\begin{array}{l}
\sum_{x=1}^{4} \sum_{y=x+1}^{5} \sum_{z=y+1}^{6} \sum_{p=1}^{5} \sum_{q=p+1}^{6} \sum_{r=1}^{6}\left(c_{x y} c_{y z} c_{z x}+c_{x z} c_{z y} c_{y x}\right)\left(c_{p q} c_{q p}\right) F_{r}+ \\
\sum_{x=1}^{2} \sum_{y=x+1}^{5} \sum_{z=x+1}^{6} \sum_{p=x+1}^{5} \sum_{q=y+1}^{6} \sum_{r=1}^{6}\left(c_{x y} c_{y z} c_{z p} c_{p q} c_{q x}+c_{x q} c_{q p} c_{p z} c_{z y} c_{y x}\right) F_{r}
\end{array}\right) \\
& +\left(\begin{array}{l}
\sum_{x=1}^{3} \sum_{y=x+1}^{5} \sum_{z=x+1}^{6} \sum_{p=y+1}^{6} \sum_{q=1}^{5} \sum_{r=q+1}^{6}\left(c_{x y} c_{y z} c_{z p} c_{p x}+c_{x p} c_{p z} c_{z y} c_{y x}\right)\left(c_{q r} c_{r q}\right)+ \\
\sum_{x=1}^{1} \sum_{y=x+1}^{5} \sum_{z=y+1}^{6} \sum_{p=1}^{4} \sum_{q=p+1}^{5} \sum_{r=q+1}^{6}\left(c_{x y} c_{y z} c_{z x}+c_{x z} c_{z y} c_{y x}\right)\left(c_{p q} c_{q r} c_{r p}+c_{p r} c_{r q} c_{q p}\right)+ \\
\sum_{x=1}^{1} \sum_{y=x+1}^{6} \sum_{z=x+1}^{3} \sum_{p=x+2}^{6} \sum_{q=z+1}^{5} \sum_{r=z+2}^{6}\left(c_{x y} c_{y x}\right)\left(c_{z p} c_{p z}\right)\left(c_{q r} c_{r q}\right)+ \\
\sum_{x=1}^{1} \sum_{y=x+1}^{5} \sum_{z=x+1}^{6} \sum_{p=x+1}^{6} \sum_{q=x+1}^{6} \sum_{r=1}^{6}\left(c_{x y} c_{y z} c_{z p} c_{p q} c_{q r} c_{r x}+c_{x r} c_{r q} c_{q p} c_{p z} c_{z y} c_{y x}\right)
\end{array}\right)
\end{aligned}
$$

Step 5. Theoretically Best and Worst Values: The theoretically best values of the factors are attained by giving the best value i.e. 5 and the theoretically worst values of the factors are attained by providing the worst value i.e. 1 . If the factor is close to its best value, it represents that it is very important in the implementation of the SCP in an industry, while if the factor is close to its worst value, the factor is not so effective in SCP adoption. 


\subsection{Spearman's Rank Correlation}

The correlation among the computed index values is described using Spearman's rank correlation coefficient. It is a non-parametric gauge of rank correlation, which defines the connection among the ranks of two factors compared to the companies in question in this research. The Spearman correlation among two values varies ( $r_{s}$ is high if observations have the same ranks among the two data sets, and low if observations have different ranks) according to the ranks of the data sets (Kumar et al., 2017). Spearman's rank correlation is extensively used by investigators in diverse domains, such as health survey for England, customer retention in automobile workshops, ecological execution analysis of Chinese industry, etc. (Martin and Springate, 2018; Kumar et al., 2017; Bi et al., 2015).

The Spearman's rank correlation coefficient is symbolized by ' $r$ ' and is given by Eq. (2) when there is no tie between ranks:

$$
r_{s}=1-\frac{6 \sum d_{i}^{2}}{n\left(n^{2}-1\right)}
$$

where:

$\mathrm{d}_{\mathrm{i}}=$ Difference between the two ranks

$\mathrm{n}=$ Number of main factors

\section{DATA ANALYSIS AND RESULTS}

\subsection{Background of Case Companies}

In India, the automobile business is holding a major position in the market. The companies in the automotive sector in India are enthusiastic about incorporating corporate ecological, societal, and financial aspects at local and worldwide levels (Luthra and Mangla, 2018). However, the Indian automotive sector has limited capacity to insert such practices completely on the shop floor. To help industries, three automobile companies operating in India are considered in this research. The companies produce light and heavy-duty vehicles, spare parts, engines for maritime purpose, diesel engine, and transmissions, two, three, and four-wheeler vehicles, military vehicles, tractors, inverters, batteries, etc. Companies believe that green technology is the need to move towards sustainability. The managers of the companies understand the importance of sustainability and green environment, and therefore, continuously working on its manufacturing operations, products, and supply chain. The companies are profoundly working towards fuel-efficiency and emissions in collaboration with the consumers, stakeholders, and suppliers. Management of the case companies is involved in a project "Responsible Consumption and Production through ICT". Management also intends to list and analyze the factors for successful SCP concepts through information systems in the supply chain.

Three automobile companies are included in this research whose profiles are given below in Table 3 .

\subsection{Data Collection and Survey Questionnaire}

In order to gather data for this work, a survey questionnaire (see Appendix A) was formed. Properly designed survey questionnaires offer reliability among respondents, more profound knowledge of the industrial practices, and predominant information quality (Synodinos, 2003). The questionnaire pretesting was done by providing a questionnaire to 5 experts ( 3 academicians and 2 industrial experts). The feedback of the experts is used to further modify the survey questionnaire. After pretesting, the applicability of the content and reliability of the questionnaire was checked. Content validity is a practice used to judge the relativity of the content of the questionnaire with the identified factors 
Table 3. Consolidated profile of automobile case companies

\begin{tabular}{|l|l|l|l|}
\hline \multicolumn{1}{|c|}{ Company's Attributes } & \multicolumn{1}{|c|}{ Company 1 } & \multicolumn{1}{c|}{ Company 2 } & \multicolumn{1}{c|}{ Company 3} \\
\hline Turnover (in USD) & 155.60 Million & 73.13 Million & 77.80 Million \\
\hline No. of Employees & More than 300 & Around 1000 & Around 1500 \\
\hline Year of establishment & 1948 & 1981 & 1945 \\
\hline Certifications & $\begin{array}{l}\text { QS 9000, ISO 9001, ISO } \\
\text { 9002, ISO 14001 }\end{array}$ & ISO-14000 & $\begin{array}{l}\text { Business world FICCI-SEDF } \\
\text { Corporate Social Responsibility } \\
\text { Award }\end{array}$ \\
\hline $\begin{array}{l}\text { Types of manufactured } \\
\text { products }\end{array}$ & $\begin{array}{l}\text { Light and heavy-duty } \\
\text { vehicles, spare parts, } \\
\text { engines for the maritime } \\
\text { purpose }\end{array}$ & $\begin{array}{l}\text { Four wheelers, } \\
\text { diesel engine, and } \\
\text { transmissions }\end{array}$ & $\begin{array}{l}\text { Two, three and four-wheeler } \\
\text { vehicles, military vehicles, tractors, } \\
\text { inverters, batteries, and gen-sets }\end{array}$ \\
\hline Nature of business & $\begin{array}{l}\text { Original equipment } \\
\text { manufacturer, Supplier }\end{array}$ & $\begin{array}{l}\text { Manufacturer, } \\
\text { Supplier }\end{array}$ & $\begin{array}{l}\text { Original equipment manufacturer, } \\
\text { Supplier }\end{array}$ \\
\hline
\end{tabular}

(Sekaran, 2016). The data is collected by opting the convenience and random sampling methods (Luthra et al., 2016):

1. Convenience Sampling: Convenience sampling is the technique in which the data was collected by visiting the case companies personally. Using convenience sampling 16 responses were collected. This technique is helpful in reducing the confusion about the content of the questionnaire while filling it.

2. Random Surveys: Among the various types of automotive industries, 25 respondents were taken to form the database. The sample size with 25 experts has been justified in the context of multiple case study research (please refer study of Mangla et al. 2015 for more details). The targeted people were arbitrarily chosen and the mail containing the survey questionnaire was sent to 20 respondents. After repetitive emails, and telephonic calls, and reminders 9 valid responses were collected and invalid/incomplete responses were discarded which results in a response rate of $45 \%$ which is considered as satisfactory for the current study (Malhotra and Grover, 1998).

For the purpose of this work, the demographic detail of the respondents is given in Table 4.

\subsection{Validation of Factors}

Initially from the literature, 15 ICT based factors for SCP in automotive supply chains were listed. Based on the survey instrument, the identified factors were validated. The feedback is used to rank the expert's rating of every factor on a scale of $1-7$ (where 1-least significant and 7-most relevant). The experts selected were highly competent professionals in the area of value chain sustainability. We decided to the factors with a rating of 1 or 2 . The experts were additionally approached to add/remove some other factors. Hence, two factors were added to the list. The added factors are - training and development of employees, and standardization procedures. Training and development of employees regarding the implementation and benefit of SCP through ICT are extremely important as it helps industries to produce and consume sustainably. With a specific goal in the present business world, organizations are contending for a profoundly qualified workforce, therefore, incorporation and interfacing training and development framework into the supply chain activities is highly significant. Trained suppliers and stakeholders help in the planning and controlling of the consumption and production of automobile parts, and hence increase the efficiency of the automobile value chain. Efficient SCP acceptance changes the vision of an industry and it requires uplifting the workers' 
Table 4. Demographic summary

\begin{tabular}{|c|c|c|c|c|}
\hline S. No. & $\begin{array}{c}\text { Demographic Details of } \\
\text { the Respondent }\end{array}$ & Criteria & $\begin{array}{c}\text { No. of } \\
\text { Respondents }\end{array}$ & Percentage \\
\hline \multirow[t]{3}{*}{1} & \multirow[t]{3}{*}{ Qualification } & Graduate & 8 & 32 \\
\hline & & Post Graduate & 15 & 60 \\
\hline & & Doctorate & 2 & 8 \\
\hline \multirow[t]{5}{*}{2} & \multirow[t]{5}{*}{ Total years of experience } & Less than 6 years & 2 & 8 \\
\hline & & $6-12$ years & 17 & 68 \\
\hline & & 13-18 years & 2 & 8 \\
\hline & & 19-24 years & 1 & 4 \\
\hline & & More than 24 years & 3 & 12 \\
\hline \multirow[t]{3}{*}{3} & \multirow[t]{3}{*}{ Type of Automobile Sector } & Private Sector & 18 & 72 \\
\hline & & Public Sector & 5 & 20 \\
\hline & & Multinational Corporation & 2 & 8 \\
\hline \multirow[t]{2}{*}{4} & \multirow[t]{2}{*}{ Type of Organization } & Original Equipment Manufacturer & 19 & 76 \\
\hline & & $\begin{array}{l}\text { Supplier to Original Equipment } \\
\text { Manufacturer }\end{array}$ & 6 & 24 \\
\hline \multirow[t]{3}{*}{5} & \multirow[t]{3}{*}{ Load capacity of vehicle } & Light duty vehicle & 11 & 44 \\
\hline & & Heavy duty vehicle & 6 & 24 \\
\hline & & Both light and heavy duty vehicles & 8 & 32 \\
\hline \multirow[t]{3}{*}{6} & \multirow[t]{3}{*}{ Type of fuel used } & Petrol engine vehicles & 3 & 12 \\
\hline & & Diesel engine vehicles & 3 & 12 \\
\hline & & Both Petrol and Diesel & 19 & 76 \\
\hline \multirow[t]{3}{*}{7} & \multirow[t]{3}{*}{ Workforce } & Less than 100 Employees & 2 & 8 \\
\hline & & 101- 300 Employees & 6 & 24 \\
\hline & & More than 300 Employees & 17 & 68 \\
\hline \multirow[t]{4}{*}{8} & \multirow[t]{4}{*}{ Years of business } & Less than 10 years & 3 & 12 \\
\hline & & $10-25$ years & 5 & 20 \\
\hline & & $25-50$ years & 7 & 28 \\
\hline & & More than 50 years & 10 & 40 \\
\hline \multirow[t]{6}{*}{9} & \multirow{6}{*}{$\begin{array}{l}\text { Yearly Turnover (in } \\
\text { Million rupees) }\end{array}$} & Less than or equal to 100 & Nil & Nil \\
\hline & & $101-500$ & 2 & 8 \\
\hline & & $501-1000$ & 3 & 12 \\
\hline & & $1001-5000$ & 4 & 16 \\
\hline & & $5001-10,000$ & 6 & 24 \\
\hline & & More than 10,000 & 10 & 40 \\
\hline \multirow[t]{3}{*}{10} & \multirow{3}{*}{$\begin{array}{l}\text { Environment management } \\
\text { system }\end{array}$} & Yes & 18 & 72 \\
\hline & & No & Nil & Nil \\
\hline & & In progress & 7 & 28 \\
\hline
\end{tabular}




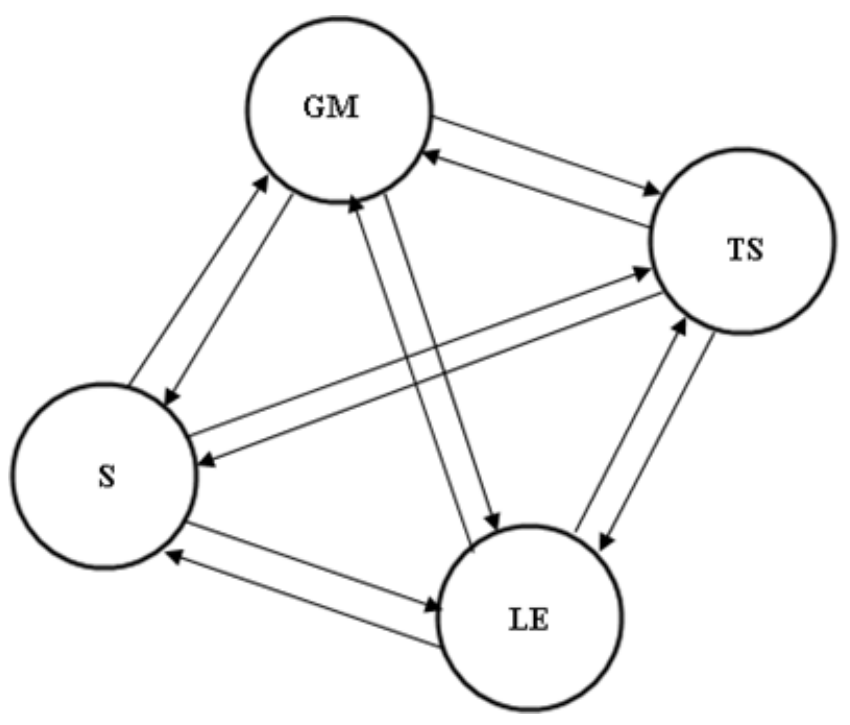

skills through training etc. In order to achieve sustainability, organizations need to follow standardized procedures to reduce waste, greenhouse gas $(\mathrm{GHG})$, and $\mathrm{CO}_{2}$ impacts throughout the supply chain and intelligently consume the raw materials. In addition, the successful adoption of SCP practices can reduce the harmful impact on the surroundings. These 17 validated factors were then divided into 4 main factors - Governance and Management (GM), Technology and Skills (TS), Legal \& Ethical (LE), and Social (S)(see Appendix B).

\subsection{Ranking the Factors Using GTMA}

After the finalization of factors, the analysis process is done by applying the GTMA technique. Based on the procedural steps, the index evaluation digraph for the main factors is plotted as shown in Figure 2. Likewise, the directed digraphs for specific factors within the main factors are formed (for details see Appendix C).

The matrix that represents the above digraphs provides one to one illustration of the main factors. These matrices are square matrices that consider all the main factors (GM, TS, LE, and S) and their relative importance $\left(c_{x y}\right)$. The matrix for the main factors of ICT is represented below in Eq. (3):

$$
I C T=\left(\begin{array}{cccc}
G M & c_{12} & c_{13} & c_{14} \\
c_{21} & T S & c_{23} & c_{24} \\
c_{31} & c_{32} & L E & c_{34} \\
c_{41} & c_{42} & c_{43} & S
\end{array}\right)
$$

In the same way, the digraph for each specific factor is converted into matrices as per the Eq. (2) (for details see Appendix D). A permanent value of the main factor - Governance and Management (GM) for all three case companies is calculated and is shown below: 


$$
\begin{aligned}
& \operatorname{Per}^{I 1}(G M)=\left(\begin{array}{lllll}
4 & 3 & 2 & 3 & 5 \\
7 & 6 & 7 & 3 & 7 \\
8 & 3 & 3 & 7 & 4 \\
7 & 7 & 3 & 5 & 4 \\
5 & 3 & 6 & 6 & 2
\end{array}\right)=2827 \times 10^{2} \\
& \operatorname{Per}^{I 2} G M=\left(\begin{array}{lllll}
5 & 3 & 7 & 4 & 6 \\
7 & 6 & 7 & 3 & 7 \\
3 & 3 & 5 & 3 & 5 \\
6 & 7 & 7 & 2 & 7 \\
4 & 3 & 5 & 3 & 4
\end{array}\right)=2671 \times 10^{2} \\
& \operatorname{Per}^{I 3}(G M)=\left(\begin{array}{lllll}
4 & 5 & 4 & 6 & 3 \\
5 & 3 & 3 & 6 & 4 \\
6 & 7 & 2 & 7 & 5 \\
4 & 4 & 3 & 3 & 3 \\
7 & 6 & 5 & 7 & 5
\end{array}\right)=2288 \times 10^{2}
\end{aligned}
$$

where, $\operatorname{Per}^{11}(\mathrm{GM}), \operatorname{Per}^{12}(\mathrm{GM})$, and $\operatorname{Per}^{13}(\mathrm{GM})$ correspondingly represent the permanent values for the factor Governance and management (GM) for the companies 1,2, and 3.Similarly, the permanent values of other main factors are shown in Appendix E.

The adoption index of ICT for all three case companies is evaluated by calculating the permanent function of matrix ICT:

$$
\begin{aligned}
\operatorname{Per}^{I 1}(I C T) & =\left(\begin{array}{cccc}
282700 & 7 & 6 & 7 \\
3 & 12438 & 4 & 8 \\
4 & 6 & 11397 & 5 \\
3 & 2 & 5 & 13704
\end{array}\right)=54917 \times 10^{13} \\
\operatorname{Per}^{I 2}(I C T) & =\left(\begin{array}{cccc}
267100 & 6 & 6 & 8 \\
4 & 13868 & 4 & 7 \\
4 & 6 & 13559 & 6 \\
2 & 3 & 4 & 11294
\end{array}\right)=56723 \times 10^{13} \\
\operatorname{Per}^{I 3}(I C T) & =\left(\begin{array}{cccc}
228800 & 6 & 5 & 8 \\
4 & 13744 & 4 & 7 \\
5 & 6 & 11012 & 7 \\
2 & 3 & 3 & 12736
\end{array}\right)=44103 \times 10^{13}
\end{aligned}
$$

The ICT adoption index values are shown in Table 5.

Next, we calculated the theoretical best and worst values. The best value for the main factor, Governance and Management (GM), is obtained as: 
Table 5. Index values of SCP factors for all three case companies

\begin{tabular}{|l|l|l|l|l|l|}
\hline & $\begin{array}{c}\text { Governance and } \\
\text { Management } \\
(\mathbf{G M})\end{array}$ & $\begin{array}{c}\text { Technology and } \\
\text { Skills (TS) }\end{array}$ & $\begin{array}{c}\text { Legal and } \\
\text { Ethical } \\
(\text { LE) }\end{array}$ & \multicolumn{1}{|c|}{ Social (S) } & \multicolumn{1}{|c|}{$\begin{array}{c}\text { ICT Focused Factor } \\
\text { Adoption Index }\end{array}$} \\
\hline Company 1 & $2827 \times 10^{2}$ & 12438 & 11397 & 13704 & $54917 \times 10^{13}$ \\
\hline Company 2 & $2671 \times 10^{2}$ & 13868 & 13559 & 11294 & $56723 \times 10^{13}$ \\
\hline Company 3 & $2288 \times 10^{2}$ & 13744 & 11012 & 12736 & $44103 \times 10^{13}$ \\
\hline Best Value & $3750 \times 10^{2}$ & 15000 & 15000 & 15000 & $12656 \times 10^{14}$ \\
\hline Worst Value & $1683 \times 10^{2}$ & 6776 & 6776 & 6776 & $52384 \times 10^{12}$ \\
\hline
\end{tabular}

$$
\operatorname{Per}(G M)^{\text {Best }}=\left(\begin{array}{ccccc}
5 & 5 & 5 & 5 & 5 \\
5 & 5 & 5 & 5 & 5 \\
5 & 5 & 5 & 5 & 5 \\
5 & 5 & 5 & 5 & 5 \\
5 & 5 & 5 & 5 & 5
\end{array}\right)=375000
$$

Similarly, the best value for SCP focused factors adoption index is:

$$
\begin{aligned}
\operatorname{Per}(I C T)^{\text {Best }} & =\left(\begin{array}{ccccc}
375000 & 5 & 5 & 5 \\
5 & 15000 & 5 & 5 \\
5 & 5 & 15000 & 5 \\
5 & & 5 & 5 & 15000
\end{array}\right)=12656 \times 10^{14} \\
\operatorname{Per}(G M)^{\text {Worst }}= & \left(\begin{array}{lllll}
1 & 5 & 5 & 5 & 5 \\
5 & 1 & 5 & 5 & 5 \\
5 & 5 & 1 & 5 & 5 \\
5 & 5 & 5 & 1 & 5 \\
5 & 5 & 5 & 5 & 1
\end{array}\right)=168376
\end{aligned}
$$

Similarly, the worst value for ICT focused factors adoption index is:

$$
\operatorname{Per}(I C T)^{\text {Worst }}=\left(\begin{array}{cccc}
168376 & 5 & 5 & 5 \\
5 & 6776 & 5 & 5 \\
5 & 5 & 6776 & 5 \\
5 & 5 & 5 & 6776
\end{array}\right)=52384 \times 10^{12}
$$

The worst and best values of the main factors are represented in Table 5. 


\subsection{Testing for SCP Adoption Index Using Spearman's Rank Correlation}

The relationship among the index values of selected automobile companies is described using Spearman's rank correlation coefficient. It is a considerable gauge to decide the point of relationship and to verify the consistency among the ranks as suggested by the professionals (Raju and Kumar, 1999). The Spearman's rank correlation coefficient is symbolized by ' $r$ ' and is computed by using Eq. (2):

$$
\begin{aligned}
& r_{s 1}=1-\frac{6 \sum d_{1}^{2}}{n\left(n^{2}-1\right)}=1-\frac{6 \times 6}{4(16-1)}=0.4 \\
& r_{s 2}=1-\frac{6 \sum d_{2}^{2}}{n\left(n^{2}-1\right)}=1-\frac{6 \times 2}{4(16-1)}=0.8 \\
& r_{s 3}=1-\frac{6 \sum d_{3}^{2}}{n\left(n^{2}-1\right)}=1-\frac{6 \times 2}{4(16-1)}=0.8
\end{aligned}
$$

Based on the above method, we can test the null hypothesis $\left(\mathrm{H}_{\mathrm{o}}\right)$. The approach of the p-value is employed for the rejection of the null hypothesis, if we have a p-value $<0.05$ and then $\mathrm{H}_{1}$ is expected to be true. The similarity among the ranks of the factors of the three companies exist with spearman's rank correlation coefficient as 0.4 between company 1 and 2, 0.8 between companies 2 and 3 , and again 0.8 between companies 1 and 3 . Further details on relative ranks of main factors for all three case companies are presented in Table 6.

\section{DISCUSSION OF FINDINGS}

The ICT focused factor indexes for three automobile companies are $54917 \times 10^{13}, 56723 \times 10^{13}$, and $44103 \times 10^{13}$. According to Table 6 , the preference order of the main factors for company 1 is Governance and Management (GM) $>$ Social (S) $>$ Technology and Skills (TS) $>$ Legal \& Ethical (LE). For company 2, it is Governance and Management (GM)> Technology and Skills (TS) $>$ Legal \& Ethical (LE) $>$ Social (S), and for company 3, it is Governance and Management (GM) $>$ Technology and Skills (TS) $>$ Social (S) $>$ Legal \& Ethical (LE). The factors having a higher index value ranks $1^{\text {st }}$ and so on. In addition, the closeness of the factor to its best value represents its importance in the SCP effectiveness in industry, whereas, if the factor is closer to its worst value, the factor is not so effective in SCP adoption.

The index values of factor 'governance and management support (GM)' for companies 1, 2, and 3 are $2827 \times 10^{2}, 2671 \times 10^{2}$, and $2288 \times 10^{2}$, respectively, which is also greater than the index values of all the other factors.

Table 6. Relative ranks of main factors

\begin{tabular}{|l|l|l|l|l|l|l|l|l|l|}
\hline Factors & Company 1 & Rank $\left(\mathbf{x}_{1}\right)$ & $\begin{array}{c}\text { Company } \\
\mathbf{2}\end{array}$ & $\operatorname{Rank}\left(\mathbf{x}_{\mathbf{2}}\right)$ & Company 3 & $\operatorname{Rank}\left(\mathbf{x}_{3}\right)$ & $\mathbf{d}_{1}{ }^{2}=\left(\mathbf{x}_{1}-\mathbf{x}_{2}\right)^{\mathbf{2}}$ & $\mathbf{d}_{2}{ }^{2}=\left(\mathbf{x}_{1}-\mathbf{x}_{3}\right)^{\mathbf{2}}$ & $\mathbf{d}_{\mathbf{3}}{ }^{2}=\left(\mathbf{x}_{2}-\mathbf{x}_{3}\right)^{\mathbf{2}}$ \\
\hline GM & $2827 \times 10^{2}$ & 1 & $2671 \times 10^{2}$ & 1 & $2288 \times 10^{2}$ & 1 & 0 & 0 & 0 \\
\hline TS & 12438 & 3 & 13868 & 2 & 13744 & 2 & 1 & 1 & 0 \\
\hline LE & 11397 & 4 & 13559 & 3 & 11012 & 4 & 1 & 0 & 1 \\
\hline S & 13704 & 2 & 11294 & 4 & 12736 & 3 & 4 & 1 & 1 \\
\hline
\end{tabular}


Governmental support and effective management play a critical role in implementing safe practices in the automotive industry in India. In India, because of the low awareness of people towards government and management policies, SCP is lacking in most of the required fields. Therefore, it is important to include governance and management support (GM) as a factor of ICT to be aware of the customers, managers, and stakeholders of the case companies. With clear directions form the government, the producers and consumers could easily understand the importance of ICT in the adoption of SCP. Further, in this research, an attempt has been made to provide ICT adoption index value, which will help Indian automobile companies to benchmark their SCP practices adoption through ICT. Based on computed ICT adoption index values, the importance of government and management support is more in case company 1 and less in case company3. It means that case company 3 needs more focus on government and management supportive policies to improve SCP practices in their organization. It has been stated that support and dedication of management are highly appreciable for SCP implementation in the industry (Zhu et al., 2005). As the public's interest in environmental issues is increasing, in response, the companies have to be transparent in their processes in value chains. Aryee et al., (2008) considered human interaction as a significant factor for an innovative framework. Carter and Rogers, (2008) revealed that to achieve sustainability all members of the supply chains should work together in an integrated way. In supply chains, coordination and cooperation among members are essential in overseeing materials and merchandise streams and in enhancing economic and service performances. The firms by working together and cooperating and sharing information with each other can meet the demand of the customers more efficiently. In order to be consistent with the organizational missions, new competencies should be established along with ICT. Such capacities do not jeopardize the upper hand of a firm and furthermore reinforce the situation of the automotive firm through the empowering impacts of good repute (Colbert and Kurucz, 2007). ICT network design and infrastructure has a significant impact on organizational changes and is significant in the successful implementation of SCP in business (Luthra et al., 2018). Using advanced design network, help companies in improving with their operational efficiency and performance (Dao et al., 2011). The changing design and infrastructure of operations and reporting standards are always associated with capacity measures, and it is mediated by arbitration and acquisition through financial resources (Ward and Zhou, 2006). Therefore, there is a need to design and implement a flexible information system to maximize the overall presentation of the network to deal with potential interference and sustainable business activities.

The index values of factor 'Technology and Skills (TS)' for companies 1, 2, and 3 are 12438, 13868, and 13744, respectively. It acquires $2^{\text {nd }}$ position in case companies 2 and 3 , and $3^{\text {rd }}$ position in case company 1 for the establishment of SCP trends through ICT, where the significance of technology and skills is more in the case automobile company 2 and lesser in the case automobile company1. Higher technological advancements act as a landmark in the path of ICT implementation. The innovative and upgraded technology helps to produce and consume sustainable products. In addition, human resources and workers' expertise eases out the production and promotion of sustainable practices. Kaushik et al., (2014) in their study found that efficient information and communication networks and expert's knowledge help in accepting innovative eco-friendly technologies in the value chain. According to Rogers, (2010), having knowledge or information about an idea or a subject is considered as the initial step in the direction of selection. This will contribute to the increase in energy efficiency and energy conservation through ICT solutions (Klimova et al., 2016). In applying ICT tools and techniques, proper knowledge and awareness provide environmental, social, and economic benefits to business organizations. As tactical practices and technological procedures are important in integrating ICT and automotive industry activities for making it resource-efficient (Erek, 2011), and thus, automotive managers need to develop their human capabilities and skills in this regard. According to Al-Sharah et al (2010), increased pressure provides creative and technically commercial opportunities in the market. ICT capabilities need consistent upgrading and ranges of abilities from the experts included 
and provide the sources that increase the operational efficiency of processes. The technical platform plays an important function in developing the IT resources of firms.

The factor 'Legal and Ethical (LE)' has the $3^{\text {rd }}$ position with index values 13559 for case company 2 and $4^{\text {th }}$ position with index values 11397 and 11012 for case companies 1 and 3 . The advancement of moral and safe practices of SCP is considered as significant towards business sustainability and SCP (Young et al., 2010). Cultural issues are significant for the automotive industry context, as the majority of resources are underutilized in companies due to ineffective structured frameworks, unproductive technologies, or informal behavior, etc (Jenkin et al., 2011). Therefore, the change in behavior is necessary. Among the sustainability conditions, Chen, (2008) has characterized these outer relations as green social capital and has discovered a certain connection among IT resource capability and the competitive advantage. An efficient IT resource capability will contribute to the increase in energy efficiency and energy conservation.

The factor 'Social (S)' comes in the $2^{\text {nd }}$ position with index value 13704 for case company $1,4^{\text {th }}$ with index value 11294 for case company2, and in the $3^{\text {rd }}$ position with index value 12736 for case industries 3. A societal benefit with safe working culture is crucial. Grabot and Schlegel (2014) have reflected that ICT applications can positively affect SCP adoption. By integrating people, processes, and planet benefits, employees can focus on developing processes for sustainable operations and the firm has been able to provide sustainability value to both the stakeholders and themselves. Active participation of customers to decide and choose ICT services is significant in promoting organizational sustainability. Currently, if firms want to avoid losing customers because of providers' poor business rehearses, managers should effectively urge their providers to work in a sustainable way (Dao et al., 2011). Thus, managers are suggested to take suitable initiatives to develop a sustainable society. In addition, managers should arrange some training sessions to change the attitude of customers towards SCP trends. Customer awareness can drive industries for prompt response in including SCP trends in business.

The index values of all the above-discussed factors are very close to their best values except factor 'Governance and Management' for case companies 2 and 3, and therefore, are highly significant in the adoption of SCP through ICT in Indian automobile case companies.

\section{RESEARCH IMPLICATIONS}

This research can assist automotive managers and practitioners in SCP adoption by improving resource utilization and coordination among members through ICT developments in an industrial context.

This research proposes the following crucial implications:

- Inform Government for Supporting ICT in SCP: Government policies and support for ICT is extremely important in SCP centered exercises in a financial and technical perspective. This helps in constant up-gradation of the processes in an organization. The government must provide standardized business procedures for automotive organizations. In this regard, the government may interact should support automotive organizations to organize conferences, workshops, seminars, symposiums etc. to develop a skill set for responsible consumption and production trends through ICT applications. The government should encourage third party involvement at the cluster level by involving academic organizations or business organizations or supported by industry associations.

- Highly Developed Digital Infrastructure: In order to adopt SCP, advanced digital infrastructure is significant as it enhances the operational-ecological-social- the excellence of organizations. For instance, the application of Industry 4.0, the Internet of Things, Big data, and Blockchain technologies can help the automotive industry to reduce wastage, improve cost, the high process, and operational control, demand management, etc. Industry 4.0 is the pattern towards automation and information trade in manufacturing technologies and procedures. The transparency provided 
by Industry 4.0 furnishes administrators with huge measures of helpful information expected to make appropriate decisions. Thus, automotive company managers need to adopt highly developed digital infrastructure to augment the general introduction of the system to manage potential obstruction and reasonable business exercises.

- Increased Collaboration Amongst Value Chain Members: In order to develop an ICT focused SCP concept, collaboration and coordination amongst the members of the value chain are highly required. This helps automotive managers improving their services and financial performances as well as reducing waste generation and improving resource efficiency. In the automobile industry, the Original Equipment Manufacturers (OEMs) should collaborate with their Tier 1 and Tier 2 suppliers for effective ICT-driven SCP practices among the suppliers. Car sharing and electric vehicles could be preferred options for achieving sustainable development goals of resource consumption and production and Industry innovation and infrastructure.

- Benchmark Services: ICT can help in superior forecasting and demand planning and improve customer service and excellent organizational-supplier relationships for sustainable energymaterial-resources consumption. Advancement in ICT empowers the business to be progressively proficient in planning, fabrication, distribution, and service of products around the world. With the help of ICT in the automotive value chain, activities like sustainable procurement, manufacturing, packaging, distribution, and real-time traffic information can be improved. The giant automotive company such as Ford Motors utilizes virtual prototype technology in the product development process to save resources, money, time, etc. Thus, Indian automotive managers are suggested to follow ICT driven benchmark practices provided by the Automotive Component Manufacturers Association of India (ACMA) for promoting sustainability and SCP concepts in business.

\section{CONCLUSION AND FUTURE WORK}

The concept of ICT has become important for business in SCP adoption. ICT driven initiatives to SCP is comparatively underdeveloped in developing nations. The reason is a lack of strategic focus in the development and implementation of ICT practices in SCP. The current research seeks to deal with ICT in improving organizational social, economic, and environmental gains. This research attempts to recognize and evaluate ICT based factors for SCP adoption in the industry.

This research seeks several unique contributions as given below:

- The concept of ICT driven initiatives to SCP is comparatively underdeveloped in developing nations, especially in India. The reason is a lack of strategic focus in the development and implementation of ICT practices in SCP. Therefore, the current research presents key ICT based factors for the adoption of SCP taking a case study of multiple Indian automobile companies. These ICT based factors assist in the establishment of responsible consumption and production aspects in an automotive value chain context. Key ICT based factors are identified with the help of a literature survey and expert input.

- The GTMA is applied to evaluate the interrelationships among and between the ICT oriented factors to SCP. Additionally, applied GTMA uncovers their level of impact in building up a sustainable culture in business.

- The Spearman's rank correlation coefficient is utilized to evaluate the relationship among the index values and to verify the consistency among the ranks.

Findings of the research reveal that the main factor 'Governance and Management' acquire the highest index value for all the three case automotive companies. The relationship between the index values of case automotive companies are further evaluated using Spearman's rank correlation coefficient. 
There are some constraints of this study, which can be considered as future work opportunities. This work is based on the perspective of the experts, so this process needs care as the opinion of experts can vary. The study comprises of the case study of three Indian automobile companies. Thus, the sample size may be increased in future studies. The proposed study might be employed to other industrial sectors such as Power, Manufacturing, Construction, etc. In addition, this work may also be extended to other developing nations, based on their stand on ICT and SCP adoption in value chains. 


\section{REFERENCES}

Abdulrahman, M. D., Gunasekaran, A., \& Subramanian, N. (2014). Critical barriers in implementing reverse logistics in the Chinese manufacturing sectors. International Journal of Production Economics, 147, 460-471. doi:10.1016/j.ijpe.2012.08.003

Ageron, B., Gunasekaran, A., \& Spalanzani, A. (2012). Sustainable supply management: An empirical study. International Journal of Production Economics, 140(1), 168-182. doi:10.1016/j.ijpe.2011.04.007

Agrawal, N., \& Agarwal, K. N. (2012). Current trends in green ict. Journal of Administration \& Governance, 7(1), 71-85.

Ahuja, V., Yang, J., \& Shankar, R. (2009). Benefits of collaborative ICT adoption for building project management. Construction Innovation, 9(3), 323-340. doi:10.1108/14714170910973529

Akenji, L., \& Bengtsson, M. (2014). Making sustainable consumption and production the core of sustainable development goals. Sustainability, 6(2), 513-529. doi:10.3390/su6020513

Aleke, B., Ojiako, U., \& Wainwright, D. W. (2011). ICT adoption in developing countries: Perspectives from small-scale agribusinesses. Journal of Enterprise Information Management, 24(1), 68-84. doi:10.1108/17410391111097438

Al-Sharrah, G., Elkamel, A., \& Almanssoor, A. (2010). Sustainability indicators for decision-making and optimisation in the process industry: The case of the petrochemical industry. Chemical Engineering Science, 65(4), 1452-1461. doi:10.1016/j.ces.2009.10.015

Andreopoulou, Z. (2012). Green Informatics: ICT for green and Sustainability. Agrárinformatika. Agrárinformatika Folyóirat, 3(2), 1-8.

Ansari, N. L., Ashraf, M. M., Malik, B. T., \& Grunfeld, H. (2010, June). Green IT awareness and practices: Results from a field study on mobile phone related e-waste in Bangladesh. In Technology and Society (ISTAS), 2010 IEEE International Symposium on (pp. 375-383). IEEE.

Apulu, I., Latham, A., \& Moreton, R. (2011). Factors affecting the effective utilisation and adoption of sophisticated ICT solutions: Case studies of SMEs in Lagos, Nigeria. Journal of Systems and Information Technology, 13(2), 125-143. doi:10.1108/13287261111135972

Aral, S., \& Weill, P. (2007). IT assets, organizational capabilities, and firm performance: How resource allocations and organizational differences explain performance variation. Organization Science, 18(5), 763-780. doi:10.1287/orsc.1070.0306

Aryee, G., Naim, M. M., \& Lalwani, C. (2008). Supply chain integration using a maturity scale. Journal of Manufacturing Technology Management, 19(5), 559-575. doi:10.1108/17410380810877258

Bansal, P., \& Clelland, I. (2004). Talking trash: Legitimacy, impression management, and unsystematic risk in the context of the natural environment. Academy of Management Journal, 47(1), 93-103.

Bi, G., Luo, Y., Ding, J., \& Liang, L. (2015). Environmental performance analysis of Chinese industry from a slacks-based perspective. Annals of Operations Research, 228(1), 65-80. doi:10.1007/s10479-012-1088-3

Brindley, C., \& Oxborrow, L. (2014). Aligning the sustainable supply chain to green marketing needs: A case study. Industrial Marketing Management, 43(1), 45-55. doi:10.1016/j.indmarman.2013.08.003

Carter, C. R., \& Rogers, D. S. (2008). A framework of sustainable supply chain management: Moving toward new theory. International Journal of Physical Distribution \& Logistics Management, 38(5), 360-387. doi:10.1108/09600030810882816

Cepolina, S. (2011). Fostering the Garment Industry Competitiveness: The ICT Contribution. Global Journal of Enterprise Information System, 3(2).

Cerri, D., \& Terzi, S. (2016). Proposal of a toolset for the improvement of industrial systems' lifecycle sustainability through the utilization of ICT technologies. Computers in Industry, 81, 47-54. doi:10.1016/j. compind.2015.09.003 
Chen, Y. S. (2008). The positive effect of green intellectual capital on competitive advantages of firms. Journal of Business Ethics, 77(3), 271-286. doi:10.1007/s10551-006-9349-1

Chugh, R., Wibowo, S., \& Grandhi, S. (2016). Environmentally sustainable Information and Communication Technology usage: Awareness and practices of Indian Information and Communication Technology professionals. Journal of Cleaner Production, 131, 435-446. doi:10.1016/j.jclepro.2016.05.004

Clark, G. (2007). Evolution of the global sustainable consumption and production policy and the United Nations Environment Programme's (UNEP) supporting activities. Journal of Cleaner Production, 15(6), $492-498$. doi:10.1016/j.jclepro.2006.05.017

Clemons, E. K., \& Row, M. C. (1991). Sustaining IT advantage: The role of structural differences. Management Information Systems Quarterly, 15(3), 275-292. doi:10.2307/249639

Colbert, B. A., \& Kurucz, E. C. (2007). Three conceptions of triple bottom line business sustainability and the role for HRM. People and Strategy, 30(1), 21.

Dao, V., Langella, I., \& Carbo, J. (2011). From green to sustainability: Information Technology and an integrated sustainability framework. The Journal of Strategic Information Systems, 20(1), 63-79. doi:10.1016/j. jsis.2011.01.002

Darvish, M., Yasaei, M., \& Saeedi, A. (2009). Application of the graph theory and matrix methods to contractor ranking. International Journal of Project Management, 27(6), 610-619. doi:10.1016/j.ijproman.2008.10.004

Du, R., Ai, S., Abbott, P., \& Zheng, Y. (2011). Contextual factors, knowledge processes and performance in global sourcing of IT services: An investigation in China. Journal of Global Information Management, 19(2), 1-26. doi:10.4018/jgim.2011040101

El Kadiri, S., Grabot, B., Thoben, K. D., Hribernik, K., Emmanouilidis, C., Von Cieminski, G., \& Kiritsis, D. (2016). Current trends on ICT technologies for enterprise information systems. Computers in Industry, 79, 14-33. doi:10.1016/j.compind.2015.06.008

Elliot, S. (2007). Environmentally sustainable ICT: a critical topic for IS research? PACIS 2007 Proceedings, 114.

Erek, K. (2011). From green IT to sustainable information systems management: Managing and measuring sustainability in IT organisations. In European, Mediterranean \& Middle Eastern Conference on Information Systems (pp. 766-781). Academic Press.

Erlandsson, J., \& Tillman, A. M. (2009). Analysing influencing factors of corporate environmental information collection, management and communication. Journal of Cleaner Production, 17(9), 800-810. doi:10.1016/j. jclepro.2008.11.021

Faisal, M. N., Banwet, D. K., \& Shankar, R. (2007). Quantification of risk mitigation environment of supply chains using graph theory and matrix methods. European Journal of Industrial Engineering, 1(1), 22-39. doi:10.1504/EJIE.2007.012652

Förster, B. (2015). Technology foresight for sustainable production in the German automotive supplier industry. Technological Forecasting and Social Change, 92, 237-248. doi:10.1016/j.techfore.2014.09.010

Gan, X., Zuo, J., Ye, K., Skitmore, M., \& Xiong, B. (2015). Why sustainable construction? Why not? An owner's perspective. Habitat International, 47, 61-68. doi:10.1016/j.habitatint.2015.01.005

Geetha, N. K., \& Sekar, P. (2016). Application of Graph Theory Matrix Approach to Select Optimal Combination of Operating Parameters on Diesel Engine to Reduce Emissions. International Journal of Chemical Sciences, 14(2).

Gholami, R., Higón, D. A., Hanafizadeh, P., \& Emrouznejad, A. (2010). Is ICT the key to development? Journal of Global Information Management, 18(1), 66-83. doi:10.4018/jgim.2010091104

Goodrum, P. M., Miller, J., Sweany, J., \& Alruwaythi, O. (2016). Influence of the format of engineering information and spatial cognition on craft-worker performance. Journal of Construction Engineering and Management, 142(9), 04016043. doi:10.1061/(ASCE)CO.1943-7862.0001157

Grabot, B., \& Schlegel, T. (2014). ICT for sustainability in industry. Computers in Industry, 65(3), 383-385. doi:10.1016/j.compind.2014.01.016 
Grant, D., \& Yeo, B. (2019). Are ICTs Really That Important in Driving Industry Performance? Journal of Global Information Management, 27(3), 101-119. doi:10.4018/JGIM.2019070106

Greco, G., Allegrini, M., Del Lungo, C., Savellini, P. G., \& Gabellini, L. (2015). Drivers of solid waste collection costs. Empirical evidence from Italy. Journal of Cleaner Production, 106, 364-371. doi:10.1016/j. jclepro.2014.07.011

Grover, S., Agrawal, V. P., \& Khan, I. A. (2006). Role of human factors in TQM: A graph theoretic approach. Benchmarking, 13(4), 447-468. doi:10.1108/14635770610676290

Gullo, K., \& Haygood, L. (2010). The Business Case for Environmental and Sustainability Employee Education. National Environmental Education Foundation.

Gunasekaran, A., \& Ngai, E. W. (2008). Adoption of e-procurement in Hong Kong: An empirical research. International Journal of Production Economics, 113(1), 159-175. doi:10.1016/j.ijpe.2007.04.012

Hack, S., \& Berg, C. (2014). The potential of IT for corporate sustainability. Sustainability, 6(7), 4163-4180. doi:10.3390/su6074163

Hassani, H., Silva, E. S., \& Al Kaabi, A. M. (2017). The role of innovation and technology in sustaining the petroleum and petrochemical industry. Technological Forecasting and Social Change, 119, 1-17. doi:10.1016/j. techfore.2017.03.003

Hearn, G., Kimber, M., Lennie, J., \& Simpson, L. (2005). A way forward: Sustainable ICTs and regional sustainability. The Journal of Community Informatics, 1(2).

Heeks, R. (2010). Do information and communication technologies (ICTs) contribute to development? Journal of International Development, 22(5), 625-640. doi:10.1002/jid.1716

Hilty, L. M., \& Aebischer, B. (2015). Ict for sustainability: An emerging research field. In ICT Innovations for Sustainability (pp. 3-36). Springer. doi:10.1007/978-3-319-09228-7_1

Hosseini, M. R., Banihashemi, S., Rameezdeen, R., Golizadeh, H., Arashpour, M., \& Ma, L. (2017). Sustainability by Information and Communication Technology: A paradigm shift for construction projects in Iran. Journal of Cleaner Production, 168, 1-13. doi:10.1016/j.jclepro.2017.08.200

India Brand Equity Foundation (IBEF). (n.d.). Automobile industry in India. Available at: Error! Hyperlink reference not valid.

Jangra, K., Grover, S., Chan, F. T., \& Aggarwal, A. (2011). Digraph and matrix method to evaluate the machinability of tungsten carbide composite with wire EDM. International Journal of Advanced Manufacturing Technology, 56(9), 959-974. doi:10.1007/s00170-011-3234-5

Jenkin, T. A., Webster, J., \& McShane, L. (2011). An agenda for 'Green'information technology and systems research. Information and Organization, 21(1), 17-40. doi:10.1016/j.infoandorg.2010.09.003

Jonsson, P., \& Mattsson, S. A. (2013). The value of sharing planning information in supply chains. International Journal of Physical Distribution \& Logistics Management, 43(4), 282-299. doi:10.1108/IJPDLM-07-2012-0204

Jurkat, W. B., \& Ryser, H. J. (1966). Matrix factorizations of determinants and permanents. Journal of Algebra, 3(1), 1-27. doi:10.1016/0021-8693(66)90016-0

Kagaari, J. R., Munene, J. C., \& Mpeera Ntayi, J. (2010). Performance management practices, information and communication technology (ICT) adoption and managed performance. Quality Assurance in Education, 18(2), 106-125. doi:10.1108/09684881011035330

Kausar, K., Garg, D., \& Luthra, S. (2017). Key enablers to implement sustainable supply chain management practices: An Indian insight. Uncertain Supply Chain Management, 5(2), 89-104. doi:10.5267/j.uscm.2016.10.005

Kaushik, A., Kumar, S., Luthra, S., \& Haleem, A. (2014). Technology transfer: Enablers and barriers-a review. International Journal of Technology. Policy and Management, 14(2), 133-159.

Keller, J., \& Heiko, A. (2014). The influence of information and communication technology (ICT) on future foresight processes-Results from a Delphi survey. Technological Forecasting and Social Change, 85, 81-92. doi:10.1016/j.techfore.2013.07.010 
Klimova, A., Rondeau, E., Andersson, K., Porras, J., Rybin, A., \& Zaslavsky, A. (2016). An international Master's program in green ICT as a contribution to sustainable development. Journal of Cleaner Production, 135, 223-239. doi:10.1016/j.jclepro.2016.06.032

Koplin, J., Seuring, S., \& Mesterharm, M. (2007). Incorporating sustainability into supply management in the automotive industry-the case of the Volkswagen AG. Journal of Cleaner Production, 15(11), 1053-1062. doi:10.1016/j.jclepro.2006.05.024

Kumar, A., Luthra, S., Khandelwal, D. K., Mehta, R., Chaudhary, N., \& Bhatia, S. (2017). Measuring and improving customer retention at authorised automobile workshops after free services. Journal of Retailing and Consumer Services, 39, 93-102. doi:10.1016/j.jretconser.2017.07.007

Lai, K. H., Wong, C. W., \& Lam, J. S. L. (2015). Sharing environmental management information with supply chain partners and the performance contingencies on environmental munificence. International Journal of Production Economics, 164, 445-453. doi:10.1016/j.ijpe.2014.12.009

Lee, H. L. (2000). Creating value through supply chain integration. Supply Chain Management Review, 4(4), 30-36.

Lu, Y., Li, Y., Skibniewski, M., Wu, Z., Wang, R., \& Le, Y. (2014). Information and communication technology applications in architecture, engineering, and construction organizations: A 15-year review. Journal of Management Engineering, 31(1), A4014010.

Luthra, S., Mangla, S. K., Chan, F. T., \& Venkatesh, V. G. (2018). Evaluating the Drivers to Information and Communication Technology for Effective Sustainability Initiatives in Supply Chains. International Journal of Information Technology \& Decision Making, 17(01), 311-338. doi:10.1142/S0219622017500419

Luthra, S., \& Mangla, S. K. (2018). When strategies matter: Adoption of sustainable supply chain management practices in emerging economy's context. Resources, Conservation and Recycling, 138, 194-206. doi:10.1016/j. resconrec.2018.07.005

Luthra, S., Garg, D., \& Haleem, A. (2016). The impacts of critical success factors for implementing green supply chain management towards sustainability: An empirical investigation of Indian automobile industry. Journal of Cleaner Production, 121, 142-158. doi:10.1016/j.jclepro.2016.01.095

Majeed, M. T. (2018). Information and communication technology (ICT) and environmental sustainability in developed and developing countries. Pakistan Journal of Commerce and Social Sciences, 12(3), 758-783.

Majid, M. E. (2018). Role of ICT in promoting sustainable consumption and production patterns-a guideline in the context of Bangladesh. Journal of Environmental Sustainability, 6(1), 1.

Malhotra, M. K., \& Grover, V. (1998). An assessment of survey research in POM: From constructs to theory. Journal of Operations Management, 16(4), 407-425. doi:10.1016/S0272-6963(98)00021-7

Mangla, S. K., Kumar, P., \& Barua, M. K. (2015). Risk analysis in green supply chain using fuzzy AHP approach: A case study. Resources, Conservation and Recycling, 104, 375-390. doi:10.1016/j.resconrec.2015.01.001

Martin, C., \& Springate, C. E. (2018). Synthetic Sample Generation Representing the English Population Using Spearman Rank Correlation and Chomsky Decomposition. Value in Health, 21, S221. doi:10.1016/j. jval.2018.04.1497

Matos, S., \& Hall, J. (2007). Integrating sustainable development in the supply chain: The case of life cycle assessment in oil and gas and agricultural biotechnology. Journal of Operations Management, 25(6), 1083-1102. doi:10.1016/j.jom.2007.01.013

Mignone, G., Hosseini, M. R., Chileshe, N., \& Arashpour, M. (2016). Enhancing collaboration in BIM-based construction networks through organisational discontinuity theory: A case study of the new Royal Adelaide Hospital. Architectural Engineering and Design Management, 12(5), 333-352. doi:10.1080/17452007.2016 .1169987

Morrar, R., Abdeljawad, I., Jabr, S., Kisa, A., \& Younis, M. Z. (2019). The Role of Information and Communications Technology (ICT) in Enhancing Service Sector Productivity in Palestine: An International Perspective. Journal of Global Information Management, 27(1), 47-65. doi:10.4018/JGIM.2019010103 
Muduli, K., Govindan, K., Barve, A., \& Geng, Y. (2013). Barriers to green supply chain management in Indian mining industries: A graph theoretic approach. Journal of Cleaner Production, 47, 335-344. doi:10.1016/j. jclepro.2012.10.030

Muduli, K., \& Barve, A. (2011). Role of green issues of mining supply chain on sustainable development. International Journal of Innovation, Management and Technology, 2(6), 484.

Murugesan, S. (2008). Harnessing green IT: Principles and practices. IT Professional, 10(1), 24-33. doi:10.1109/ MITP.2008.10

Nourani, Y., \& Andresen, B. (1999). Exploration of NP-hard enumeration problems by simulated annealingThe spectrum values of permanents. Theoretical Computer Science, 215(1), 51-68. doi:10.1016/S03043975(99)80002-4

Orlikowski, W. J. (2008). Using technology and constituting structures: A practice lens for studying technology in organizations. In Resources, co-evolution and artifacts (pp. 255-305). Springer. doi:10.1007/978-1-84628901-9_10

Pero, M., Moretto, A., Bottani, E., \& Bigliardi, B. (2017). Environmental collaboration for sustainability in the construction industry: An exploratory study in Italy. Sustainability, 9(1), 125. doi:10.3390/su9010125

Pick, J. B., \& Azari, R. (2011). A global model of technological utilization based on governmental, businessinvestment, social, and economic factors. Journal of Management Information Systems, 28(1), 49-84. doi:10.2753/ MIS0742-1222280103

Porter, M. E., \& Kramer, M. R. (2006). The link between competitive advantage and corporate social responsibility. Harvard Business Review, 84(12), 78-92. PMID:17183795

Puri, S. K., \& Sahay, S. (2007). Role of ICTs in participatory development: An Indian experience. Information Technology for Development, 13(2), 133-160. doi:10.1002/itdj.20058

Rai, A., Patnayakuni, R., \& Seth, N. (2006). Firm performance impacts of digitally enabled supply chain integration capabilities. Management Information Systems Quarterly, 30(2), 225-246. doi:10.2307/25148729

Raju, K. S., \& Kumar, D. N. (1999). Multi-criterion decision making in irrigation planning. Agricultural Systems, 62(2), 117-129. doi:10.1016/S0308-521X(99)00060-8

Rao, R. V. (2007). Decision making in the manufacturing environment: using graph theory and fuzzy multiple attribute decision making methods. Springer Science \& Business Media.

Rao, R. V. (2006). A decision-making framework model for evaluating flexible manufacturing systems using digraph and matrix methods. International Journal of Advanced Manufacturing Technology, 30(11), 1101-1110. doi:10.1007/s00170-005-0150-6

Rogers, E. M. (2010). Diffusion of innovations. Simon and Schuster.

Romm, J. (2002). The internet and the new energy economy. Resources, Conservation and Recycling, 36(3), 197-210. doi:10.1016/S0921-3449(02)00084-8

Russo, M. V., \& Fouts, P. A. (1997). A resource-based perspective on corporate environmental performance and profitability. Academy of Management Journal, 40(3), 534-559.

Saguy, I. S., \& Sirotinskaya, V. (2014). Challenges in exploiting open innovation's full potential in the food industry with a focus on small and medium enterprises (SMEs). Trends in Food Science \& Technology, 38(2), 136-148. doi:10.1016/j.tifs.2014.05.006

Sekaran, U., \& Bougie, R. (2016). Research methods for business: A skill building approach. John Wiley \& Sons.

Simchi-Levi, D., Kaminsky, P., Simchi-Levi, E., \& Shankar, R. (2008). Designing and managing the supply chain: concepts, strategies and case studies. Tata McGraw-Hill Education.

Synodinos, N. E. (2003). The "art" of questionnaire construction: Some important considerations for manufacturing studies. Integrated Manufacturing Systems, 14(3), 221-237. doi:10.1108/09576060310463172

Takase, K., \& Murota, Y. (2004). The impact of IT investment on energy: Japan and US comparison in 2010. Energy Policy, 32(11), 1291-1301. doi:10.1016/S0301-4215(03)00097-1 
Tatoglu, E., Bayraktar, E., Golgeci, I., Koh, S. L., Demirbag, M., \& Zaim, S. (2016). How do supply chain management and information systems practices influence operational performance? Evidence from emerging country SMEs. International Journal of Logistics Research and Applications, 19(3), 181-199. doi:10.1080/1 3675567.2015.1065802

Taylor, P. (2015). The importance of information and communication technologies (ICTs): An integration of the extant literature on ICT adoption in small and medium enterprises. International Journal of Economics. Commerce and Management, 3(5), 274-295.

Techatassanasoontorn, A. A., Huang, H., Trauth, E. M., \& Juntiwasarakij, S. (2011). Analyzing ICT and Development: Thailand's path to the information economy. Journal of Global Information Management, 19(1), 1-29. doi:10.4018/jgim.2011010101

Trentesaux, D., Borangiu, T., \& Thomas, A. (2016). Emerging ICT concepts for smart, safe and sustainable industrial systems. Computers in Industry, 81, 1-10. doi:10.1016/j.compind.2016.05.001

Van Breedam, A. (2016). Future-proofing supply chains. In Sustainable Logistics and Supply Chains (pp. 53-73). Springer. doi:10.1007/978-3-319-17419-8_3

Vickery, S. K., Jayaram, J., Droge, C., \& Calantone, R. (2003). The effects of an integrative supply chain strategy on customer service and financial performance: An analysis of direct versus indirect relationships. Journal of Operations Management, 21(5), 523-539. doi:10.1016/j.jom.2003.02.002

Ward, P., \& Zhou, H. (2006). Impact of information technology integration and lean/just-in-time practices on lead-time performance. Decision Sciences, 37(2), 177-203. doi:10.1111/j.1540-5915.2006.00121.x

Wath, S. B., Vaidya, A. N., Dutt, P. S., \& Chakrabarti, T. (2010). A roadmap for development of sustainable E-waste management system in India. The Science of the Total Environment, 409(1), 19-32. doi:10.1016/j. scitotenv.2010.09.030 PMID:20951410

Wu, S. J., \& Raghupathi, W. (2015). The Strategic Association between Information and Communication Technologies and Sustainability: A Country-Level Study. Journal of Global Information Management, 23(3), 92-115. doi:10.4018/JGIM.2015070105

Yang, L. R., \& Huang, C. F. (2016). Information technology utilization to improve project team-owner relationship and project performance. KSCE Journal of Civil Engineering, 20(1), 48-57. doi:10.1007/s12205-015-0147-0

Young, W., Hwang, K., McDonald, S., \& Oates, C. J. (2010). Sustainable consumption: Green consumer behaviour when purchasing products. Sustainable Development, 18(1), 20-31.

Zhang, J., Luna-Reyes, L. F., Jarman, H., \& Tayi, G. K. (2015). Information systems to support sustainable consumption and sustainable supply. Information Technology Management, 16(1), 1-4. doi:10.1007/s10799014-0206-0

Zhang, X., Pieter van Donk, D., \& van der Vaart, T. (2011). Does ICT influence supply chain management and performance? A review of survey-based research. International Journal of Operations \& Production Management, 31(11), 1215-1247. doi:10.1108/01443571111178501

Zhou, X., Zhou, D., \& Wang, Q. (2018). How does information and communication technology affect China's energy intensity? A three-tier structural decomposition analysis. Energy, 151, 748-759. doi:10.1016/j. energy.2018.03.115

Zhu, Q., Sarkis, J., \& Geng, Y. (2005). Green supply chain management in China: Pressures, practices and performance. International Journal of Operations \& Production Management, 25(5), 449-468. doi:10.1108/01443570510593148 


\section{APPENDIX A}

\section{Survey Questionnaire}

Dear Sir/Madam,

Greetings of the day!!

This work aims to list and evaluate ICT based factors, which are responsible for the implementation of SCP in an industrial context. These factors of ICT have noteworthy effect on environment, economy and society, and help enhance the proficiency and profitability of the automotive value chain. The information for this work is gathered in 3 stages, whose details are given as:

\section{Phase 1: Company Identifier Information}

1. Name of the Company:

2. Location:

3. Type of Automobile Sector:
a. Public Sector
b. Private Sector
c. Multinational Corporation
d. Regulatory Bodies
e. If other, please specify.

4. Type of Organization:
a. Original Equipment Manufacturer
b. Supplier to Original Equipment Manufacturer
c. If other, please specify

5. Load capacity of vehicle:
a. Light duty vehicle
b. Heavy duty vehicle

6. Type of fuel used:
a. Petrol engine vehicles
b. Diesel engine vehicles
c. Electric vehicles
d. If other, please specify

7. Workforce:
a. Less than 100
b. $101-300$
c. More than 300

8. Years of business:
a. Less than 10 years
b. 10-25 years
c. 25-50 years
d. More than 50 years

9. Annual Turnover (in Million rupees):
a. Less than or equal to 100
b. 101-500
c. 501-1000
d. 1001-5000
e. 5001-10,000
f. More than 10,000

10. Does your organization have an environmental management system?

a. Yes 

b. No
c. In Progress

Demographic Details of the Respondent

1. Gender:
a. Male
b. Female

2. Qualification:
a. Graduate
b. Post Graduate
c. Doctorate
d. If other, please specify

3. Age:

4. Total years of experience:
a. Less than 6 years
b. 6-12 years
c. 13-18 years
d. 19-24 years
e. More than 24 years

5. Position:

6. Your responsibility:

\section{Phase 2: Validating the Factors}

There are four main factors and seventeen specific factors are identified in this work. Please put your responses to add/delete/reword for any other factors relevant to SCP adoption in Indian automotive industry context. Tables 7-10 show the factors of ICT to SCP adoption in a supply chain context listed from literature.

Table 7. Governance and management

\begin{tabular}{|l|l|l|}
\hline \multicolumn{1}{|c|}{ GM } & \multicolumn{1}{|c|}{ Governance and Management } & Degree of Priority \\
\hline GM1 & $\begin{array}{l}\text { Government policies and encouragement in SCP through } \\
\text { information system }\end{array}$ & \\
\hline GM2 & Higher coordination and cooperation among members & \\
\hline GM3 & Change management & $\begin{array}{l}\text { Advanced digital infrastructure and cost effective models in era of } \\
\text { Industry 4.0 }\end{array}$ \\
\hline GM4 & Competitiveness and globalization & \\
\hline GM5 & (Please indicatesome other sub-factor if any) & \\
\hline GM6 & (Please indicate some other sub-factor if any) & \\
\hline GM7 &
\end{tabular}


Table 8. Technology and skills

\begin{tabular}{|l|l|l|}
\hline \multicolumn{1}{|c|}{ TS } & \multicolumn{1}{|c|}{ Technology and Skills } & Degree of Priority \\
\hline TS1 & Understanding and awareness of ICT tools among stakeholders & \\
\hline TS2 & Human expertise on ICT tools and techniques & \\
\hline TS3 & Technological up-gradations and process innovation & \\
\hline TS4 & (Please indicate some other sub-factor if any) & \\
\hline TS5 & (Please indicate some other sub-factor if any) & \\
\hline
\end{tabular}

Table 9. Legal and ethical

\begin{tabular}{|l|l|l|}
\hline \multicolumn{1}{|c|}{ LE } & \multicolumn{1}{|c|}{ Legal and Ethical } & Degree of Priority \\
\hline LE1 & Cultural factors & \\
\hline LE2 & Transparency mechanism for responsible management & \\
\hline LE3 & Higher security, privacy and trust in business environment & \\
\hline LE4 & (Please indicate some other sub-factor if any) & \\
\hline LE5 & (Please indicate some other sub-factor if any) & \\
\hline
\end{tabular}

Table 10. Social

\begin{tabular}{|l|l|l|}
\hline \multicolumn{1}{|c|}{ S } & \multicolumn{1}{|c|}{ Social } & Degree of Priority \\
\hline S1 & Integration of people-process-planet benefits & \\
\hline S2 & Customer preferences towards ICT in SCP & \\
\hline S3 & Managing people and supply chain resources & \\
\hline S4 & Encourage private and foreign investment & \\
\hline S5 & (Please indicate some other sub-factor if any) & \\
\hline S6 & (Please indicate some other sub-factor if any) & \\
\hline
\end{tabular}

\section{Phase 3: Determine the Priority of Factors}

After listing the main factors and specific factors, we seek to analyze them for knowing their priority of concern. Thus, please put your responses by utilizing the given scale.

Table 11. Relative importance of factors $\left(c_{x y}\right)$

\begin{tabular}{|c|c|c|}
\hline \multirow{2}{*}{ Definition } & \multicolumn{2}{|c|}{ Relative Importance of $f=$ Factors } \\
\hline & $\mathbf{c}_{\mathrm{xy}}$ & $c_{y x}=10-c_{x y}$ \\
\hline Evaluating factors are evenly essential & 5 & 5 \\
\hline An evaluating factor is moderately essential above other factor & 6 & 4 \\
\hline An evaluating factor is strongly essential above other factor & 7 & 3 \\
\hline An evaluating factor is very strongly essential above other factor & 8 & 2 \\
\hline An evaluating factor is extremely essential above other factor & 9 & 1 \\
\hline An evaluating factor is exceptionally above other factor & 10 & 0 \\
\hline
\end{tabular}




\section{APPENDIX B}

\section{ICT Basedfactors to Adopt SCP}

\section{Table 12. ICT driven factors to adopt SCP}

\begin{tabular}{|c|c|c|c|}
\hline S.No. & ICT Factors & Description & References \\
\hline \multicolumn{4}{|c|}{ (i) Governance and Management (GM) } \\
\hline 1 & $\begin{array}{l}\text { Government } \\
\text { policies and } \\
\text { support in } \\
\text { SCP through } \\
\text { information } \\
\text { system (GM1) }\end{array}$ & $\begin{array}{l}\text { Government policies and supportfor adopting ICT } \\
\text { based resources and infrastructure is crucial for } \\
\text { organizations in SCP adoption. }\end{array}$ & $\begin{array}{l}\text { Zhang et al., 2015; Elliot, 2007; Puri } \\
\text { and Sahay, } 2007\end{array}$ \\
\hline 2 & $\begin{array}{l}\text { Higher } \\
\text { coordination } \\
\text { and cooperation } \\
\text { among members } \\
\text { (GM2) }\end{array}$ & $\begin{array}{l}\text { For aneffective SCP concept, managementneeds } \\
\text { to developconfidence among value chain } \\
\text { members. Coordination and sharing of } \\
\text { information is important for management between } \\
\text { stakeholders and the members of the value chain } \\
\text { to improve SCP adoption }\end{array}$ & $\begin{array}{l}\text { Pero et al. (2017); Murugesan, 2008; } \\
\text { Matos and Hall, } 2007\end{array}$ \\
\hline 3 & $\begin{array}{l}\text { Change } \\
\text { management } \\
(\mathrm{GM} 3)\end{array}$ & $\begin{array}{l}\text { Currently, ICT can acts as a change management } \\
\text { for organizations to drive SCP concepts in their } \\
\text { value chain activities. }\end{array}$ & $\begin{array}{l}\text { Tatoglu et al. (2016); Gunasekaran } \\
\text { and Ngai, (2008) }\end{array}$ \\
\hline 4 & $\begin{array}{l}\text { Advanced digital } \\
\text { infrastructure } \\
\text { and cost effective } \\
\text { models in era } \\
\text { of Industry } 4.0 \\
\text { (GM4) }\end{array}$ & $\begin{array}{l}\text { In order to implement SCP, ICT requires an } \\
\text { efficient and accurate information communication } \\
\text { network between the producers and consumers, } \\
\text { and along with the system }\end{array}$ & $\begin{array}{l}\text { Jonsson and Mattsson, 2013; } \\
\text { Hossein et al., 2017; Dao et al., } 2011\end{array}$ \\
\hline 5 & $\begin{array}{l}\text { Competitiveness } \\
\text { and globalization } \\
\text { (GM5) }\end{array}$ & $\begin{array}{l}\text { Globalization and competitiveness are pushing } \\
\text { organizations to adopt SCP through ICT processes } \\
\text { and operations }\end{array}$ & Cepolina, 2011 \\
\hline \multicolumn{4}{|c|}{ (ii) Technology and Skills (TS) } \\
\hline 1 & $\begin{array}{l}\text { Understanding } \\
\text { and awareness of } \\
\text { ICT tools among } \\
\text { stakeholders } \\
\text { (TS1) }\end{array}$ & $\begin{array}{l}\text { Stakeholder's understanding and awareness about } \\
\text { ICT tools is highly encouraged for adoption of } \\
\text { sustainability in the business }\end{array}$ & $\begin{array}{l}\text { Hossein et al., 2017; Kausar et al., } \\
2017\end{array}$ \\
\hline 2 & $\begin{array}{l}\text { Human expertise } \\
\text { on ICT tools and } \\
\text { techniques (TS2) }\end{array}$ & $\begin{array}{l}\text { Human expertise is an important factor in } \\
\text { promoting ICT patterns, which can increase the } \\
\text { effectiveness of SCP adoption in supply chain }\end{array}$ & $\begin{array}{l}\text { Clemons and Row, 1991; } \\
\text { Abdulrahman et al., } 2014\end{array}$ \\
\hline 3 & $\begin{array}{l}\text { Technological } \\
\text { up-gradations } \\
\text { and process } \\
\text { innovation (TS3) }\end{array}$ & $\begin{array}{l}\text { Technological updates and process innovations are } \\
\text { highly appreciated to improve information network } \\
\text { and SCP practices in industry. }\end{array}$ & $\begin{array}{l}\text { Ansari et al., 2010; Erek, 2011; } \\
\text { Kausar et al. 2017; El Kadiri et al., } \\
2016\end{array}$ \\
\hline 4 & $\begin{array}{l}\text { Training and } \\
\text { development of } \\
\text { employees (TS4) }\end{array}$ & $\begin{array}{l}\text { Training and development of employees about ICT } \\
\text { is crucial to adopt SCP trends in valuechains }\end{array}$ & Expert's input \\
\hline
\end{tabular}


Table 12. Continued

\begin{tabular}{|c|c|c|c|}
\hline S.No. & ICT Factors & Description & References \\
\hline \multicolumn{4}{|c|}{ (iii) Legal \& Ethical (LE) } \\
\hline 1 & $\begin{array}{l}\text { Cultural factors } \\
\text { (LE1) }\end{array}$ & $\begin{array}{l}\text { Cultural factors are significant in the successful } \\
\text { execution of ICT to promote SCP }\end{array}$ & $\begin{array}{l}\text { Ahuja et al., 2009; Hearn et al., } \\
\text { 2005; Orlikowski, } 2008\end{array}$ \\
\hline 2 & $\begin{array}{l}\text { Transparency } \\
\text { mechanism for } \\
\text { responsible } \\
\text { management } \\
\text { (LE2) }\end{array}$ & $\begin{array}{l}\text { The traceability mechanism for monitoring } \\
\text { product/process wastageis an imperative aspect of } \\
\text { business sustainability }\end{array}$ & $\begin{array}{l}\text { Ansari et al., 2010; Hossein et al., } \\
\text { 2017; Greco et al., } 2015\end{array}$ \\
\hline 3 & $\begin{array}{l}\text { Higher security, } \\
\text { privacy and } \\
\text { trust in business } \\
\text { environment } \\
\text { (LE3) }\end{array}$ & $\begin{array}{l}\text { Organizations need to ensure higher security, } \\
\text { privacy and trust among members in setting } \\
\text { up ICT system. This would further help in } \\
\text { accomplishing sustainable development objective } \\
\text { sin business. }\end{array}$ & $\begin{array}{l}\text { Keller and Heiko, 2014; Ageron et } \\
\text { al., 2012;Trentesaux et al., 2016; Du } \\
\text { et al.,2011 }\end{array}$ \\
\hline 4 & $\begin{array}{l}\text { Standardization } \\
\text { procedures (LE4) }\end{array}$ & $\begin{array}{l}\text { ICT system can help organizations to fix the issue } \\
\text { of standardization }\end{array}$ & Expert's input \\
\hline \multicolumn{4}{|c|}{ (iv) Social (S) } \\
\hline 1 & $\begin{array}{l}\text { Integration of } \\
\text { people-process- } \\
\text { planet benefits } \\
\text { (S1) }\end{array}$ & $\begin{array}{l}\text { ICT based processes and operations can } \\
\text { assist organizations in integrating people, } \\
\text { process and planet's aspects in sustainable } \\
\text { businessdevelopment }\end{array}$ & $\begin{array}{l}\text { Pero et al. (2017); Van Breedam, } \\
\text { 2016; Zhang et al., } 2011\end{array}$ \\
\hline 2 & $\begin{array}{l}\text { Customer } \\
\text { preferences } \\
\text { towards ICT in } \\
\text { SCP }(\mathrm{S} 2)\end{array}$ & $\begin{array}{l}\text { Participation of customers to decide and choose } \\
\text { ICT services can play animportant role in } \\
\text { promoting organizational sustainability. }\end{array}$ & $\begin{array}{l}\text { Aleke et al., 2011; Apulu et al., } \\
\text { 2011; Kagaari et al., } 2010\end{array}$ \\
\hline 3 & $\begin{array}{l}\text { Managing people } \\
\text { and supply chain } \\
\text { resources (S3) }\end{array}$ & $\begin{array}{l}\text { IT assets can empower firms to create } \\
\text { sustainability capacities through coordination with } \\
\text { individuals and SCM resources }\end{array}$ & Dao et al., 2011 \\
\hline 4 & $\begin{array}{l}\text { Encourage } \\
\text { private and } \\
\text { foreign } \\
\text { investment (S4) }\end{array}$ & $\begin{array}{l}\text { Encouraging private and foreign investment is an } \\
\text { important factor to strengthen ICT infrastructure } \\
\text { and capabilities to improve the people- } \\
\text { process-planet gains of business organizations. }\end{array}$ & $\begin{array}{l}\text { Kumar et al. (2013); Vickery et al. } \\
\text { (2003); Saguy and Sirotinskaya } \\
\text { (2014) }\end{array}$ \\
\hline
\end{tabular}




\section{APPENDIX C}

\section{Behavioral Digraph for Specific Factors to ICT}

Figure 3. Digraph for factor Governance and Management (GM)

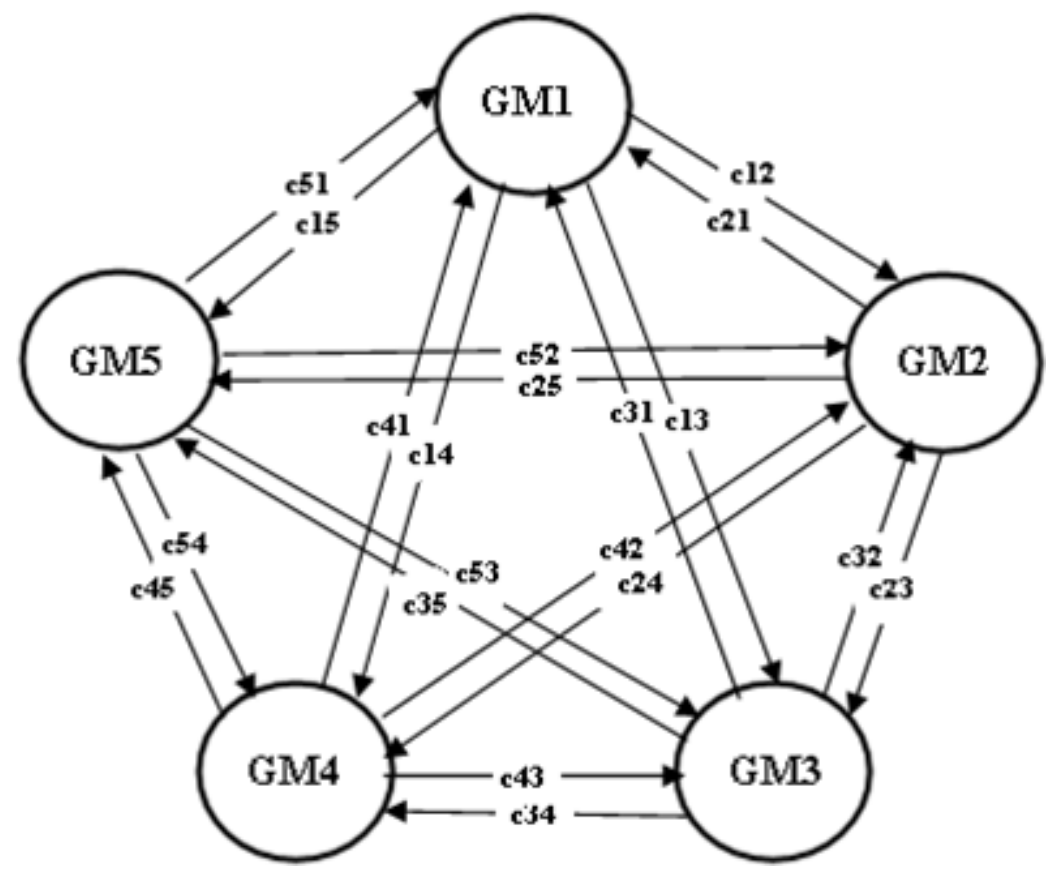

Figure 4. Digraph for factor Technology and Skills (TS)

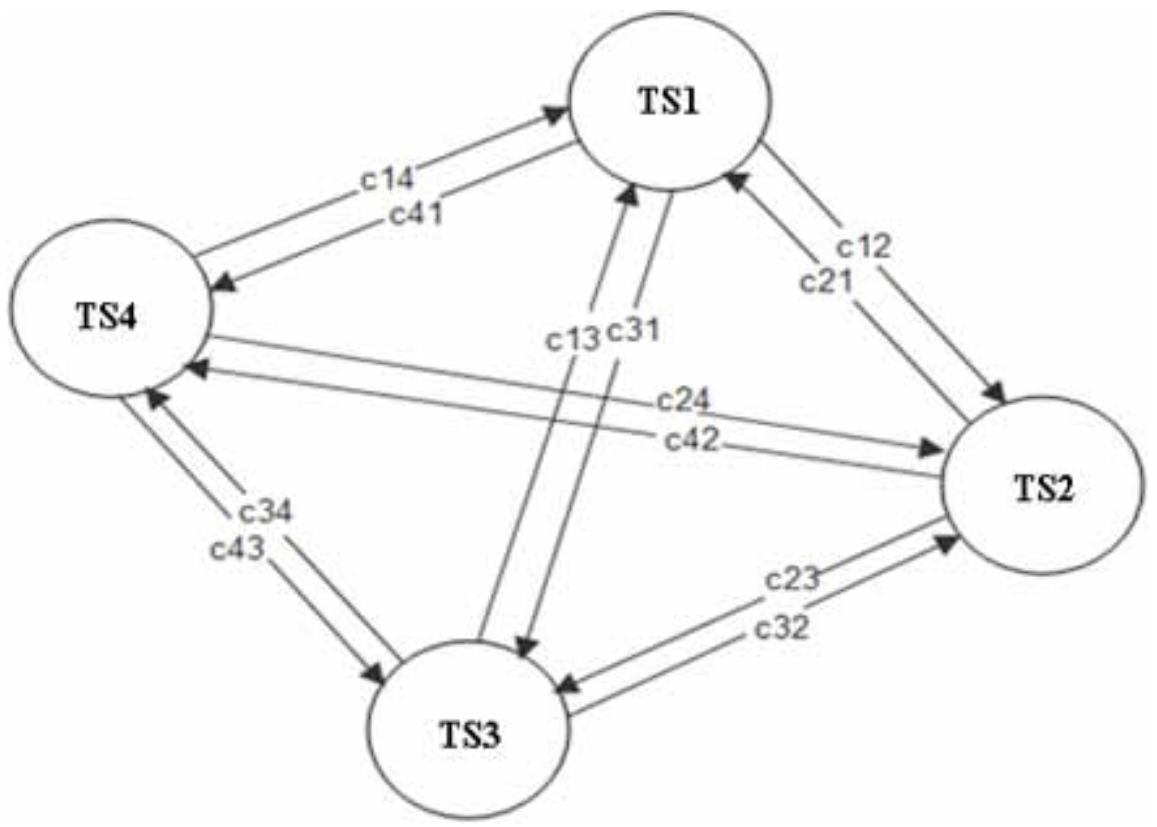


Figure 5. Digraph for factor Legal and Ethical (LE)

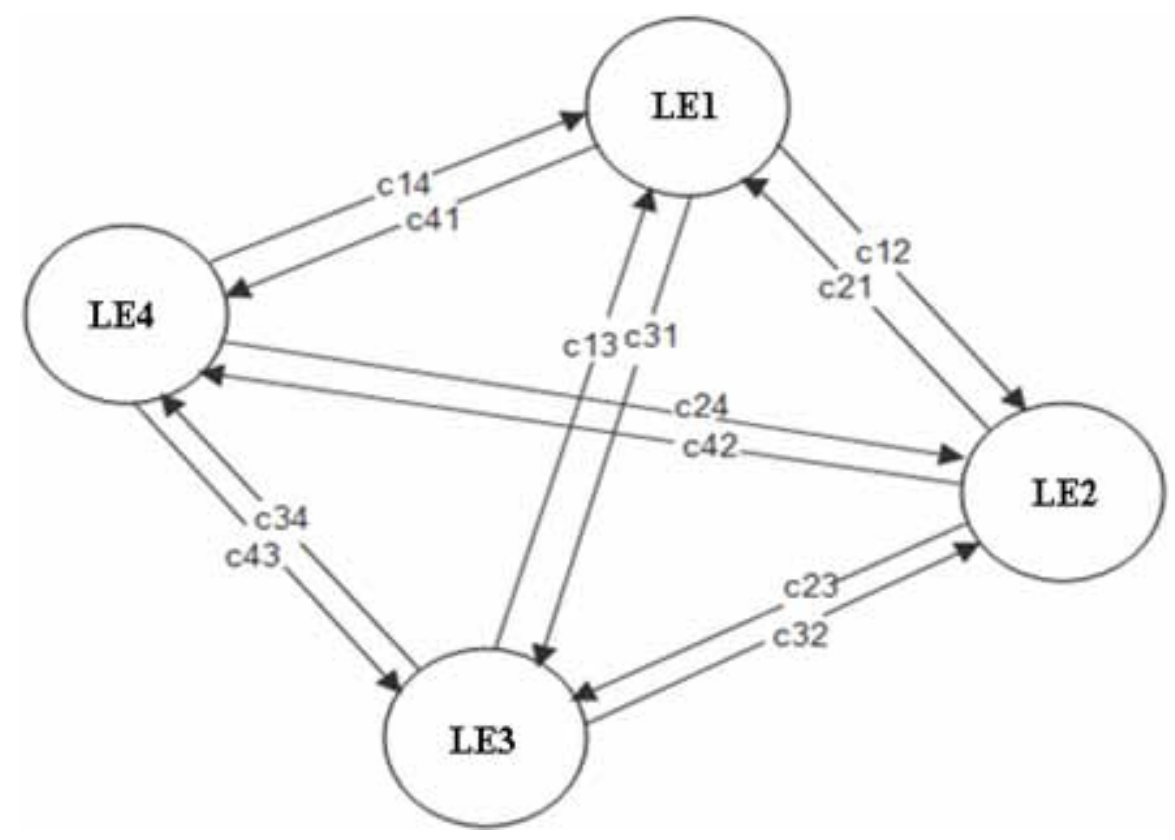

Figure 6. Digraph for factor Social (S)

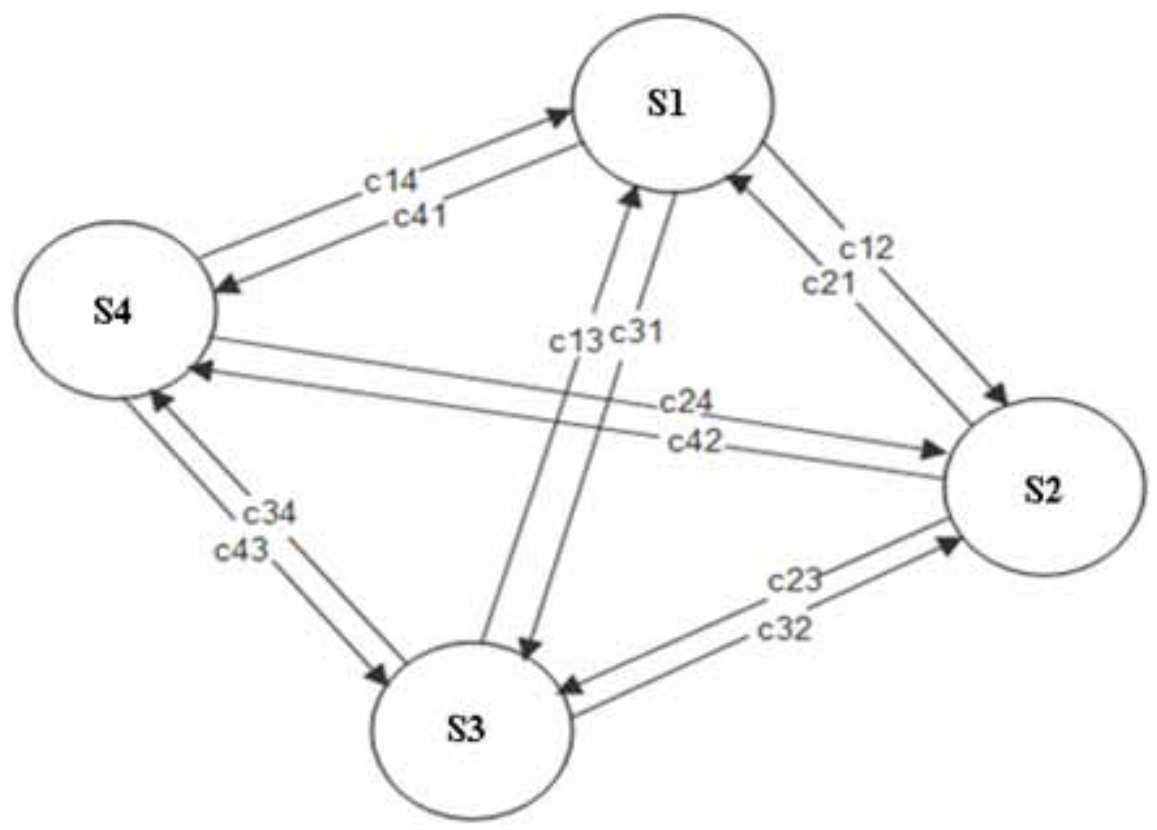




\section{APPENDIX D}

\section{Matrix Representation}

$$
\begin{aligned}
& \operatorname{Per}(G M)=\left(\begin{array}{lllll}
G M 1 & c_{12} & c_{13} & c_{14} & c_{15} \\
c_{21} & G M 2 & c_{23} & c_{24} & c_{25} \\
c_{31} & c_{32} & G M 3 & c_{34} & c_{35} \\
c_{41} & c_{42} & c_{43} & G M 4 & c_{45} \\
c_{51} & c_{52} & c_{53} & c_{54} & G M 5
\end{array}\right) \\
& \operatorname{Per}(T S)=\left(\begin{array}{cccc}
T S 1 & c_{12} & c_{13} & c_{14} \\
c_{21} & T S 2 & c_{23} & c_{24} \\
c_{31} & c_{32} & T S 3 & c_{34} \\
c_{41} & c_{42} & c_{43} & T S 4
\end{array}\right) \\
& \operatorname{Per}(L E)=\left(\begin{array}{cccc}
L E 1 & c_{12} & c_{13} & c_{14} \\
c_{21} & L E 2 & c_{23} & c_{24} \\
c_{31} & c_{32} & L E 3 & c_{34} \\
c_{41} & c_{42} & c_{43} & L E 4
\end{array}\right) \\
& \operatorname{Per}(S)=\left(\begin{array}{lllll}
S 1 & c_{12} & c_{13} & c_{14} \\
c_{21} & S 2 & c_{23} & c_{24} \\
c_{31} & c_{32} & S 3 & c_{34} \\
c_{41} & c_{42} & c_{43} & S 4
\end{array}\right)
\end{aligned}
$$




\section{APPENDIX E}

\section{Permanent Values of Specific Factors}

$$
\begin{aligned}
& \operatorname{Per}^{I 1}(T S)=\left(\begin{array}{llll}
2 & 5 & 6 & 7 \\
5 & 4 & 6 & 3 \\
4 & 4 & 6 & 4 \\
3 & 7 & 6 & 5
\end{array}\right)=12438 \\
& \operatorname{Per}^{2}(T S)=\left(\begin{array}{llll}
6 & 6 & 3 & 5 \\
4 & 5 & 7 & 4 \\
7 & 3 & 3 & 5 \\
5 & 6 & 5 & 4
\end{array}\right)=13868 \\
& \operatorname{Per}^{I 3}(T S)=\left(\begin{array}{llll}
4 & 4 & 6 & 4 \\
6 & 5 & 3 & 7 \\
4 & 7 & 6 & 5 \\
6 & 3 & 5 & 3
\end{array}\right)=13744 \\
& \operatorname{Per}^{I 1}(L E)=\left(\begin{array}{llll}
4 & 7 & 4 & 6 \\
3 & 2 & 4 & 7 \\
6 & 6 & 6 & 7 \\
4 & 3 & 3 & 5
\end{array}\right)=11397 \\
& \operatorname{Per}^{I 2}(L E)=\left(\begin{array}{llll}
3 & 6 & 5 & 6 \\
4 & 5 & 7 & 4 \\
5 & 3 & 7 & 3 \\
4 & 6 & 7 & 4
\end{array}\right)=13559 \\
& \operatorname{Per}^{I 3}(L E)=\left(\begin{array}{llll}
5 & 4 & 3 & 2 \\
6 & 4 & 4 & 6 \\
7 & 6 & 3 & 7 \\
8 & 4 & 3 & 5
\end{array}\right)=11012 \\
& \operatorname{Per}^{I 1}(S)=\left(\begin{array}{llll}
4 & 6 & 4 & 4 \\
4 & 6 & 7 & 5 \\
6 & 3 & 5 & 6 \\
6 & 5 & 4 & 3
\end{array}\right)=13704 \\
& \operatorname{Per}^{I 2}(S)=\left(\begin{array}{llll}
3 & 8 & 6 & 3 \\
2 & 4 & 4 & 7 \\
4 & 6 & 4 & 5 \\
7 & 3 & 5 & 2
\end{array}\right)=11294 \\
& \operatorname{Per}^{I 3}(S)=\left(\begin{array}{llll}
4 & 5 & 7 & 3 \\
5 & 6 & 5 & 4 \\
3 & 5 & 3 & 4 \\
7 & 6 & 6 & 5
\end{array}\right)=12736
\end{aligned}
$$


Surbhi Uniyal is currently pursuing research work for Ph.D. degree in mechanical engineering from Graphic Era (Deemed to be University), Dehradun, India. He is also working as assistant professor in mechanical engineering department of Graphic Era (Deemed to be University), India. Her current research interests include supply chain management, operations management and SCP.

Sachin Kumar Mangla is working as a Faculty of Knowledge Management and Business Decision Making, University of Plymouth, United Kingdom. Dr Sachin is working in the field of Green and Sustainable Supply Chain and Operations; Industry 4.0; Circular Economy; Decision Making and Modelling. He has a teaching experience of more than five years in Supply Chain and Operations Management and Decision Making, and currently associated in teaching with various universities in UK, Turkey, India, China, France, etc. He is committed to do and promote high quality research. He has published/presented several papers in repute international/national journals (International Journal of Production Economics; International Journal of Production Research; Production Planning and Control; Business Strategy and the Environment; Journal of Cleaner Production; Annals of Operations Research; Transportation Research Part - D; Transportation Research Part - E; Renewable and Sustainable Energy Reviews; Resource Conservation and Recycling; Information System Frontier; Management Decision; International Journal of Logistics Research and Applications; Benchmarking an International Journal; Industrial Data and Management System; International Journal of Quality and Reliability Management) and conferences (POMS, SOMS, IIIE, CILT - LRN, GLOGIFT). He has an h-index 35, i10-index 65, Google Scholar Citations of around 4000. He is involved in editing couple of Special issues as a Guest Editor in Production Planning \& Control: The Management of Operations, and Resources, Recycling and Conservation, Annals of Operations Research, Journal of Resource Policy, Journal of Cleaner Production, and 'Technological Forecasting and Social Change' on various issues of 'Industry 4 and Circular Economy' and Green and Sustainable Supply Chains Performance Improvement' and 'Food Supply Chains' 'and 'Industry 4.0, Cleaner Production, Circular Economy and Ethical Business Development'. Currently, he is also involved in several research projects on various issues and applications of Circular economy and Sustainability. Among them, he is responsible for knowledge based decision model in "Enhancing and implementing knowledge based ICT solutions within high risk and uncertain conditions for agriculture production systems (RUC-APS)", European Commission RISE scheme, €1.3M. Recently, he has also received a grant as a PI from British Council - Newton Fund Research Environment Links Turkey/UK - Circular and Industry 4.0 driven sustainable solutions for reducing food waste in supply chains in Turkey. He is also working with USERC (Uttarakhand Science Education \& Research Centre), Govt of Uttarakhand, India for managing food waste in Circular Economy. He is also a professional member of Indian Institution of Industrial Engineers (India); OPERATIONAL RESEARCH SOCIETY OF INDIA; Society of Operations Management (SOMS); Multiple Criteria Decision Making (MCDM) Society; System Dynamics Society, UK.

PRS Sarma is currently associated with Production and Operations Management area as Associate Professor in Indian Institute of Management Visakhapatnam, India. Dr. Sarma, PhD and MBA from Indian Institute of TechnologyDelhi in the Department of Management Studies. Dr. Sarma has more than 20 years of wide and varied Industry experience in the field of ICT in Lean Production systems, Project Execution etc. Visited more than 30 countries in connection with Project executions including Austria, Algeria, Bangladesh, Benin, Botswana, Burkina-Faso, Denmark, Egypt, France, Ghana, Ivory-coast, Japan, Kenya, Kingdom of Saudi Arabia, Latvia, Malaysia, Mauritius, Morocco, Nepal, Norway, Russia, Singapore, Sri Lanka, Syria, Sweden, Togo, Tunisia and USA etc. His research has been published in reputed journals.

Ming-Lang Tseng (Institute of Innovation and Circular Economy, Asia University, Taichung, Taiwan). Lecture in English-Strategic Management, Eco-Innovation in Business Management, Operations Management, Green Supply Chain Management, Sustainable Supply Chain Management. Research Interests include Sustainable supply chain management, Corporate sustainability, Sustainable development indicators, Sustainable consumption and production, Multi-criteria decision-making methods, Fuzzy set theory etc.

Pravin P. Patil has received M. Tech (Machine Design) and PhD (Mech. Engg.) degrees from the Indian Institute of Technology, Roorkee. Presently he is working as Professor in mechanical engineering at Graphic Era University. He has published more than 120 research papers in highly indexed international journals and conferences. He is an expert reviewer for various international journals in his areas of research like IEEE/ASME Transaction of Mechatronics, ISA transactions of Elsevier etc. He has got Young Scientist Award for the year 2013 (Research Grant of Rs. 18.3 Lakhs) from Department of Science and Technology (DST), New Delhi, Govt. of India. He is a recipient of MHRD / QIP Fellowship award of Govt. of India. He is recipient of Meritorious Research Performance award at Graphic Era University, Dehradun. He is consistently involved in teaching and research since last 20 years at various reputed institutes in India and has taught several core courses like Engineering Mechanics, Strength of Materials, Machine design etc. as well as advanced courses like Finite element method, Mechanical vibrations etc. His research area is multidisciplinary which includes Finite Element Analysis, Mechatronics, Mechanical vibration, Soft Computing Techniques, Computational statistics techniques etc. 